DIW BERLIN

Discussion

Papers
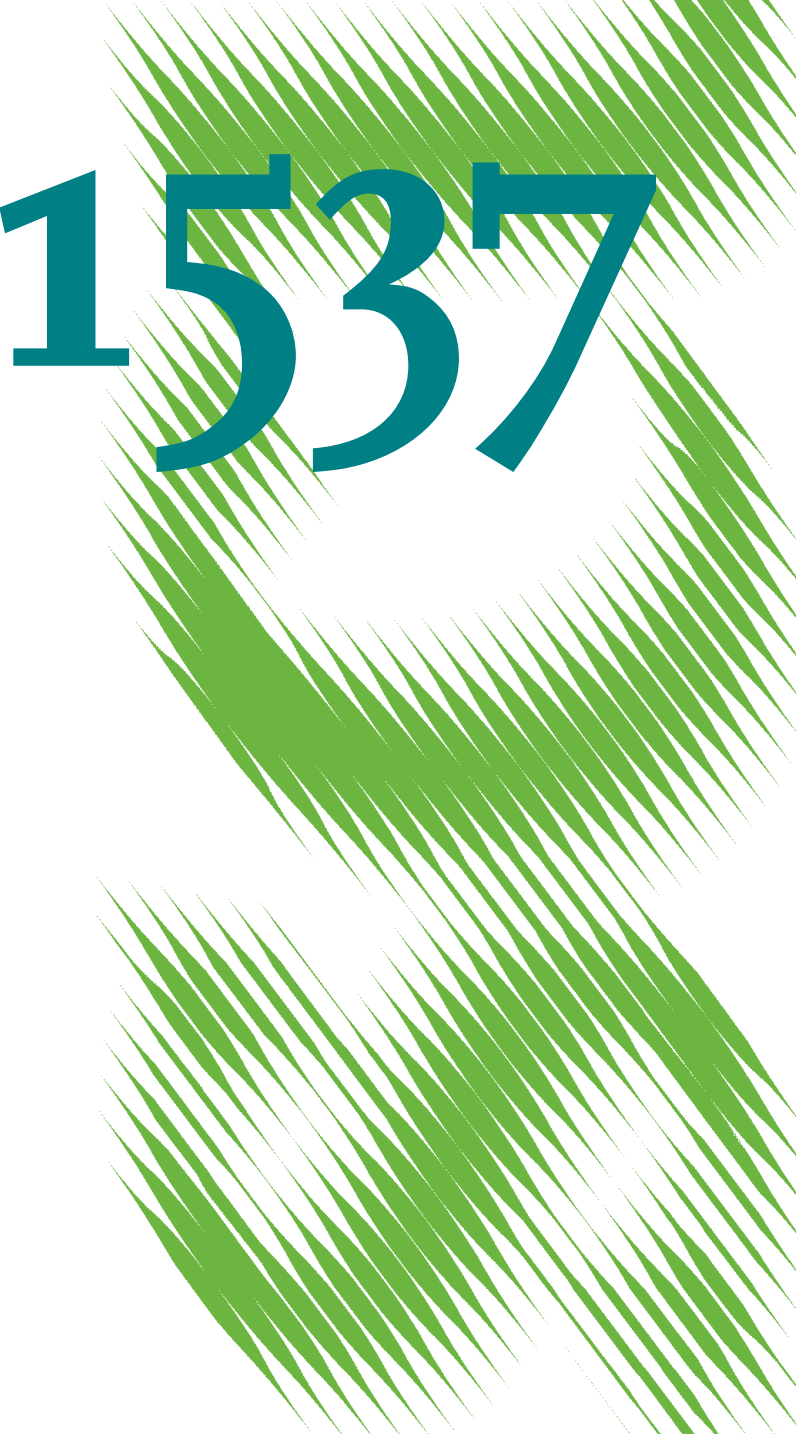

MMI

MMMMMMMMMM

Food Intake and the

Role of Food Self-Provisioning 
Opinions expressed in this paper are those of the author(s) and do not necessarily reflect views of the institute.

IMPRESSUM

(C) DIW Berlin, 2015

DIW Berlin

German Institute for Economic Research

Mohrenstr. 58

10117 Berlin

Tel. +49 (30) $89789-0$

Fax +49 (30) $89789-200$

http://www.diw.de

ISSN electronic edition 1619-4535

Papers can be downloaded free of charge from the DIW Berlin website:

http://www.diw.de/discussionpapers

Discussion Papers of DIW Berlin are indexed in RePEc and SSRN:

http://ideas.repec.org/s/diw/diwwpp.html

http://www.ssrn.com/link/DIW-Berlin-German-Inst-Econ-Res.html 


\title{
Food intake and the role of food self-provisioning
}

\author{
Katharina Lehmann-Uschner ${ }^{a}$ and Kati Kraehnert ${ }^{b}$
}

18 December 2015

\begin{abstract}
This paper investigates the role of food self-provisioning for the intake of macro- and micronutrients of households in Mongolia. Our analysis is based on rich household survey data that collected food consumption through consumption diaries. We analyze nutritional outcomes within and across the three prevalent Mongolian livelihoods that derive food from different sources: urban wave employees, rural households with small herds, and pastoralists with large herds. Results show that food consumption patterns differ strongly across the three livelihoods, with herding households having a better nutrition situation. Moreover, food self-provisioning significantly affects dietary quality and quantity. Farming food crops improves the nutrient intake of small herders. In contrast, the provision of food through animal husbandry activities has ambivalent effects on households' diet. It increases the intake of calories and nutrients from animal sources, while it decreases the intake of carbohydrates and nutrients from vegetal sources. This finding suggests household-specific market failures due to remoteness exist. Last, exposure to a severe weather event did not negatively affect households' energy intake, but it reduces the intake of nutrient from animal sources.
\end{abstract}

Key words: food-self provisioning, herding, nutrition, Mongolia, shock

JEL codes: 012,132

\section{Acknowledgements}

We are grateful for helpful comments from Veronika Bertram-Huemmer, Valeria Groppo, Friederike Lenel, Adam Lederer, Lukas Menkhoff, Thomas Otter, Amartuvshin Tserennadmid, and Natascha Wagner. The research was generously funded by the German Federal Ministry of Education and Research, funding line "Economics of Climate Change", research grant 01LA1126A. The responsibility for the content of this paper lies solely with the authors.

a German Institute for Economic Research (DIW Berlin), Mohrenstr. 58, 10117 Berlin, Germany, email klehmann@diw.de

b Corresponding author, German Institute for Economic Research (DIW Berlin), Mohrenstr. 58, 10117 Berlin, Germany, email kkraehnert@diw.de 



\section{Introduction}

Since the early 2000s, major achievements in the fight against global hunger have been made: The number of people suffering from hunger dropped from 927 million to 795 million between 2006 and 2015 (FAO et al. 2015). Yet, a quarter of children worldwide are stunted, a sign of chronic malnutrition (De Onis et al. 2012). Furthermore, micronutrient deficiencies, often termed hidden hunger, continue to be a central nutritional and developmental problem. Worldwide, over 2 billion people suffer from micronutrient deficiencies (Welthungerhilfe et al. 2014), which has important individual and societal consequences. Inadequate intake of key nutrients, particularly during early childhood, can impair subsequent physical, cognitive and behavioral development (e.g., Arlappa et al. 2011; De Onis et al. 2012; Grantham-McGregor et al. 1999; Victora et al. 2008), which in turn may cause lower productivity and foregone GDP (World Bank 2006b).

In this paper, we investigate the role of food self-provisioning for the macro- and micronutrient intake of Mongolian households. The context of Mongolia is a particularly interesting case for studying nutrition as the Mongolian population engages in strikingly diverse livelihoods. On the one hand, there are herders who produce a large share of their own food. The group of herding households comprises both (semi-) nomadic pastoralists who use animal husbandry as their main source of sustenance and households tending smaller number of animals complementary to other income activities. On the other hand, there are urban wage earners who buy most of their food from markets. The three livelihood groups also face different degrees of market imperfections in food and agricultural outputs markets that range from being close to perfect in urban areas to completely missing for at least some food groups in remote rural areas.

Our study analyzes nutritional outcomes among households following three different types of livelihoods that derive food from different sources. We explore nutrient wealth elasticities across and within livelihood groups. Our analysis accounts for the share of calories produced by animal husbandry activities within the household and, separately, for the household's farming activities. Moreover, we explore the impact of one extreme weather event on nutrient intake and food self-provisioning. Our focus is on the extremely harsh 2001/02 winter - 
called $d z u d$ in Mongolian - that caused the death of about 11 percent of the national livestock. The outcome measures of interest are the daily quantities of calories, carbohydrates, fat (animal and vegetal), proteins (animal and vegetal), vitamin A and iron consumed per adult equivalent. The database for our analyses is the nationally representative HIES/LSMS household survey implemented in 2002/03. The survey provides exceptionally rich data on food consumption: Consumption diaries covering more than 90 food items were filled out by each sample household over a 12 week period.

Our study builds on and adds to the literature focusing on the determinants of nutrition demand in developing countries. Early studies in this field primarily tested empirically whether households' consumption of calories increases when economic conditions improve, irrespective of whether income is generated in agriculture or other economic sectors. Here, the common approach is to estimate the income elasticity of calorie consumption, with consumption expenditures often used as proxy for income (see Strauss and Thomas 1995 for a review of early studies). An emerging field of research focusses on the intake of micro- and macronutrients. This shift in focus is due to the fact that even though households may maintain their calorie consumption when facing higher or lower income, this relationship provides little information on how the consumption of nutrients and dietary diversity responds to changes in income. Overall, results regarding the income elasticity for calories as well as other micro- and macro nutrients are very diverse across empirical contexts (see Skoufias et al. 2009 for a summary).

A related, but rather heterogeneous field of research tackles the link between nutrition and agricultural production at the household level. While many agricultural policies implicitly assume that a strong link exists between agricultural production and food consumption, recent reviews of the literature conclude that robust empirical evidence on this link is still scarce (Carletto et al. 2015; Haddad 2013; Ruel et al. 2013). Within this field, a small number of studies explore the role of food self-provisioning through the household's own agricultural activities for nutrition. ${ }^{1}$ For instance, Muller (2009) analyzes the role of food crop production in rural Rwanda in the mid-1980s, a context in which rural markets work imperfectly and rural households are close to autarkic in important staple foods. Muller finds evidence for a strong relationship between the value of the harvest of the main food crops and the BMI of

\footnotetext{
1 As Ruel et al. (2013) and Carletto et al. (2015) point out, the link between agricultural production and nutrition may also go through income effects, food prices, as well as women's status and health. Yet, the latter two channels are not the topic of this paper, and hence we do not discuss them here.
} 
adults, while this relationship is weak for health outcomes. Moreover, several studies in a special issue of the Journal of Development Studies (Carletto et al. 2015) explore the role of food self-production on various outcomes. Azzari et al. (2015), for example, find that the ownership of different livestock species among poor households in rural Uganda might affect their consumption of animal sourced foods, thus helping improve nutritional outcomes. Hoddinott et al. (2015) analyze the impact of household agricultural production on nutritional outcomes in rural Ethiopia, finding that cow ownership increases milk consumption and reduces stunting, which the authors attribute to market imperfections in the dairy sector. Kumar et al. (2015) investigate the link between agricultural production diversity and dietary diversity at the household level in Zambia, finding a strong positive association between the two.

Our study contributes to this literature in two ways. First, most existing studies capture food self-provisioning with rather coarse measures, such as an indicator variable for cow ownership (Hoddinott et al. 2015; Slavchevska 2015), an indicator variable for the ownership of a garden (Gibson and Rozelle 2002), an indicator variable for urban farming or livestock activities (Tasciotti and Wagner 2015), and the value of crops grown by the household (Muller 2009; Slavchevska 2015). These coarse measures have two potential drawbacks: On the one hand, they render it hard to grasp the exact contribution of food self-provisioning to nutrition. On the other, it is difficult to pinpoint whether the effect works through an income channel or immediately through the consumption of self-produced foods. To the best of our knowledge, the study by Shively and Sununtnasuk (2015) is among the few controlling explicitly for the amount of self-produced food. Using a similar approach, the rich HIES/LSMS dataset allows us to calculate the share of consumed calories stemming from the household's own production, thus accounting precisely for the extent of food subsistence. Moreover, we test whether food self-provisioning affects nutrient wealth elasticities.

Second, there is little evidence to date on the effect of shocks on food consumption. Within the small existing literature, studies particularly focus on the impact of food price shocks on nutrition (e.g., Arndt et al. 2012; Block 2004; D'Souza and Jolliffe 2014; Jensen and Miller 2008). There are few studies directly analyzing the impact of extreme weather events on nutrition. One exception is the study by Arlappa et al. (2011), which observes a significantly lower vitamin A intake among pre-school children in rural India during severe droughts. Moreover, despite the severe damage caused by the extremely harsh 2001/02 winter in 
Mongolia, we are not aware of any quantitative study investigating the causal effects of $d z u d$ exposure on Mongolian households.

Results reveal that food self-provisioning affects both dietary quantity and quality. Herding households consume significantly more calories, carbohydrates, animal fats, animal proteins, vitamin $\mathrm{A}$ and iron than do non-herding households, holding income and all other factors constant. When accounting for the self-provisioning of food in greater detail, we find that farming food crops has a significant and positive effect on the consumption of calories, carbohydrates, nutrients from vegetal sources, and iron. This effect is especially strong for small-scale herders. In contrast, the self-provisioning of meat and dairy products has ambivalent effects on household food consumption. Herding households that produce a large share of consumed calories through animal husbandry activities have a higher overall intake of energy, nutrients from animal sources, and vitamin A. At the same time, those households consume fewer nutrients from carbohydrates and vegetal sources, the nutrients for which Mongolian households already have the greatest deficiencies. Moreover, the self-provisioning of food lowers the income elasticities of most nutrients, thus making household food consumption less dependent on short-term fluctuations in income. In contrast to expectations, exposure to the severe 2001/02 winter does not significantly affect household energy intake. Yet, exposure to the shock reduces the consumption of animal fat for both small-scale and large-scale herding households. In addition, for small-scale herding households living in shock-affected areas, the link between food self-production and nutrition becomes weaker for the intake of calories, carbohydrates, animal proteins, and vitamin A compared to herders in less shock-affected areas.

The paper proceeds as follows. Section 2 provides an overview of livelihoods in Mongolia. Section 3 introduces the household survey data. The estimation strategy is outlined in section 4 , followed by a discussion of descriptive and multivariate results in section 5 . The final section concludes.

\section{Livelihoods, well-being and nutrition in Mongolia}

\subsection{Different livelihoods}

Mongolia is characterized by an extreme continental climate that features extreme variations in seasonal and daily temperatures. Winters in Mongolia are cold and long, with temperatures 
dropping to an average of $-30^{\circ}$ Celsius for several weeks. In rural areas, the climate is most suitable for herding using extensive production techniques, with animals grazed on open rangelands, while there are few opportunities for commercial farming. Thus, "unfavorable climatic conditions severely affect the food system" (Kachondham et al. 1992, p. 226).

People in Mongolia follow strikingly different livelihoods: On the one hand, a large share of the population (about 30.9 percent) lived from herding activities in 2002 (NSO 2003), when the household survey data analyzed in this paper were collected. The number of households that own at least one animal (but that may have additional sources of income) is even larger, making up about 42.6 percent of the population (ibid.). The total number of livestock in the country was 23.9 million in 2002 (ibid.). The majority of herders is nomadic or seminomadic, moving their herds anywhere between two and 20 or more times per year, usually returning to the same campsites. Herders typically own a mix of five species that are adapted to the extreme continental climate: sheep, goats, horses, cattle, and camel. Sheep provide most of the meat for households' subsistence needs. Cattle primarily provide milk that is used for dairy products as well as meat. Cashmere wool derived from goats is an important source of cash income. Horses and camels are mainly used for tending smaller livestock and for transportation; they are also considered a prestigious form of storing wealth. All animal species are also sold (alive, slaughtered, including their hides) as need arises.

On the other hand, urban households (about 57.4 percent of the population in 2002 (NSO 2003)) mostly earn their income from wage employment and small businesses, buying their food from stores and markets. Since the late 1990s, the capital city of Ulaanbaatar experienced rapid population growth. In 2002, about 34.2 percent of the national population lived in Ulaanbaatar (ibid.). In urban areas, the public sector is an important employer (employing 19 percent of the national labor force), followed by production (14.3 percent), wholesale and retail trade (12 percent), and services (9.2 percent) (ibid.).

Poverty estimates show large disparities between rural and urban areas. About 43.4 percent of the rural population and 30.3 percent of the urban population fell below the official poverty line in 2002 (NSO et al. 2004). These poverty rates (calculated from the same household survey data that we draw upon in this paper) are based on food and non-food expenditures, following a Cost of Basic Needs approach (ibid.). The nutritional situation of the Mongolian population is also suboptimal. Recent surveys indicate a large variation in caloric intake, including a group of individuals consuming less than the recommended amount of calories 
per day (Tserennadmid 2011). There are persistently high levels of chronic malnutrition among young children, with the proportion of stunted children ranging between 20 and 30 percent (Bolormaa et al. 2003; Groppo and Schindler 2014; National Statistical Office and UNICEF 2007; Public Health Institute et al. 2006). Vitamin A and iron deficiencies among children are particularly severe (Bolormaa et al. 2003; Lander et al. 2008).

\subsection{Extreme weather events}

One commonly identified factor driving poverty in Mongolia is extremely harsh winters ( $d z u d s)$ that cause mass livestock losses (Goodland et al. 2009; World Bank 2006a). Dzuds are caused by various climatic conditions, often by a combination of several events (Batima 2006, p. 57; Murphy 2011, p. 32-33). Among them are too little precipitation (either in the preceding summer or during the winter) that limit vegetation growth; excessive snow fall that prevent animals from grazing; extremely cold temperatures that sharply raise the required calories for animals; and fluctuations in winter temperatures above and below zero degree Celsius, causing snow to melt and then ice over, thus making it difficult for animals to reach the grass. Dzuds are reinforced by local geographic features, such as the ecological zone, altitude and location on a slope. As meteorological conditions vary unexpectedly in time and space, it is difficult to predict when and where dzuds occur. With global warming and climate change, such events are likely to occur more frequently in the future (IPCC 2012).

Figure 1 represents the development of the Mongolian livestock sector since 1960. With the fall of the Soviet Union ${ }^{2}$ and the beginning of the transition to a market economy, the number of livestock grew rapidly during the 1990s. Then, between 1999 and 2002, three consecutive dzud winters caused excessive livestock death, thus reversing what had been a decade of positive development of the herding economy. About 3.5, 4.8, and 2.9 million livestock died in the winter of 1999/00, 2000/01 and 2001/02, respectively. Yet, in each winter different regions of the country were hit by the dzud. ${ }^{3}$ In our analysis, we focus exclusively on the impact of the dzud in the winter of 2001/02 on food intake, which occurred immediately before the household survey was implemented. Our decision to exclude the impact of the two

\footnotetext{
2 Although it was not formally a member of the Soviet Union, Mongolia belonged since 1924 to the so-called Soviet satellite states.

3 The correlation in the district-level dzud intensity (see section 4 for a definition) across the three dzud years is weak. The coefficient of correlation between the measures of 2000/01 and 2001/02 is -0.11 , between the measures of $1999 / 00$ and $2001 / 02$ is 0.07 , and between $1999 / 00$ and $2000 / 01$ is -0.01 . This again underlines the argument that dzuds are exogenous to household decision-making.
} 
earlier dzuds is informed by stylized facts of the development economics literature, which finds that households commonly practice consumption smoothing when facing shocks (e.g., Ersado et al. 2003; Hoddinott 2006; Zimmerman and Carter 2003). ${ }^{4}$

The socioeconomic consequences of dzuds are severe. The public social safety net had virtually collapsed at the beginning of the transition period and formal insurance markets are not well developed in rural Mongolia. Apart from emergency aid provided by the government and international agencies on an ad hoc basis, herding households were largely left to their own devices, using informal strategies to cope with the consequences of dzuds (Skees and Enkh-Amgalan 2002). Yet, given the severity and covariate nature of dzuds within localities, the effectiveness of informal risk management mechanisms is limited; consequently, "high levels of livestock mortality are often unavoidable even for the most experienced herders" (Mahul and Skees 2007, p. 10). A large number of herders lost a large share of their herd and could no longer sustain a livelihood in the herding economy. Between 1999 and 2002, the number of herding households dropped by 7.36 percent (NSO 2003).

\section{Data}

Our analysis builds on the Household Income and Expenditure Survey / Living Standards Measurements Survey (HIES/LSMS) collected in Mongolia by the National Statistical Office of Mongolia (NSO), the World Bank, and UNDP in 2002-2003. The data originally stem from two separate surveys: The HIES recorded household consumption and income over a period of three consecutive months as well as basic household demographics. The HIES was implemented between February 2002 and January 2003, with roughly an equal share of households interviewed every month. ${ }^{5}$ Building on the 2000 population census as the sampling frame, a two-stage stratified survey design was used to draw the HIES sample, which comprises of approximately 11,200 households. The LSMS revisited a random

\footnotetext{
4 We also test if the dzud in the winters of 1999/00 and 2000/01 influenced food consumption, but - in line with our expectations - we do not find systematic patterns (results available upon request).

5 One particularity of the data is that the HIES was implemented on a quarterly basis. That is, 25 percent of the sample households were interviewed in the first quarter of 2002; another 25 percent of households were interviewed in the second quarter of 2002 and so on. Interviews started in the first month in each quarter and households were revisited once in each of the following two months. Interviews were not carried on into the next quarter. Thus, if a given household could not be interviewed in the first month, there are only two observations for the household. An exception to this rule is the first quarter: Interviews started in February 2002; to make this quarter complete, households were reinterviewed in January 2003. In each quarter, households were interviewed in all provinces and in all strata. Therefore, each quarterly sample can be roughly considered as representative of the population.
} 
subsample of 3,308 households between March and July 2003, on average nine months after the HIES interview took place. The LSMS questionnaire captures the socio-economic status of the sampled households in great detail. In addition to recording the demographic composition of households, the LSMS questionnaire included modules on education, health, migration, employment, herding and farming, housing, remittances, income, and durables. All analyses presented in the following account for the survey design.

The HIES data provide a very detailed record of food consumption. Each household in the sample was asked to fill in a consumption diary for three consecutive months, ${ }^{6}$ which the enumerators left with the households during their first visit. The diary documents the quantity consumed, purchased, self-produced within the household, sold, received as gift, and given away as gift for 92 food items across 10 categories: (i) meat and meat products; (ii) milk and dairy products; (iii) flour and flour products; (iv) vegetables; (v) fruits; (vi) sweets; (vii) tea, coffee and beverages; (viii) spices; (ix) alcohol and tobacco; as well as (x) meals eaten away from home. The outcome of interest is in the quantity consumed per household, which we adjust to the number of guests staying overnight. ${ }^{7}$ We then aggregate the nutrients included in the various food items consumed within the household. This is done using food composition tables prepared by the Mongolian Ministry of Health in 2009 that contain the nutrient value per 100 gram or milliliter for almost all food items from the household questionnaire. ${ }^{8}$ Food consumed outside the homestead is excluded, as information on the nutritional content is not available. $^{9}$ The total amount of nutrients consumed in the household is then scaled to

\footnotetext{
${ }^{6}$ In the months of February and July, the consumption of food and non-food items is exceptionally high, as two major festivities take place during these months (as described in greater detail in section 5.1). For this reason, we exclude February and July from all analyses (except Figure 1). To avoid bias stemming from considering different numbers of months per household, we also omit observations from the first month of the other two quarters (April and October) from the analysis and only keep those households that completed the consumption diary for the two remaining months in the quarter.

7 The data contain detailed information on the number of guest nights in each month. The total of these guest nights divided by the number of days per month is then added to the household size as average additional household member when calculating nutrition levels at the individual level.

8 Seven food items from the household questionnaire are not reported in the food composition table. Their nutrient content is proxied with the nutrient content of similar food items.

9 As a robustness test, we proxy for the food consumed outside the home by multiplying its monetary value with the average amount of calories per 1,000 Mongolian tugrik (MNT). All main results on the determinants of calories intake are maintained. As expected, the point estimate for the income elasticity is slightly higher in this regression as it includes more expensive calories consumed and the point estimate for own production is slightly lower. However, differences between the regression including and excluding consumption outside the homestead are not statistically significant.
} 
household composition. Specifically, adult equivalent ratios that take the age of household members into account are used. ${ }^{10}$

The measures obtained indicate the quantity of nutrients consumed per day per adult equivalent. It is important to note that these measures do not represent actual food consumed per individual, as it is not observed how food is allocated among household members. Instead, the measures represent proxies for food consumption, assuming that food was shared according to the age factors used in calculating adult equivalent ratios. Great care was given to perform quality checks and detect potential outliers in the nutrition variables. Following common practice in the literature (e.g., Skoufias et al. 2009), we exclude all observations exhibiting daily per adult equivalents of calorie consumption below 500 or above 6000 calories. ${ }^{11}$ The NSO has implemented HIES regularly since the 1960 s, thus both the diary design, the number of food items recorded, as well as data collection and processing procedures are settled. This underscores the reliability of the nutrition data.

Household income - collected on a monthly basis at the same time as the consumption diaries - consists of five components: income derived from wage work, non-agricultural enterprise, transfers (remittances, pensions, and rents), herding, and farming. Income was adjusted for seasonal and locational price differences, using a Paasche price index. ${ }^{12}$ Income is expressed in adult equivalents and normalized per day. We exclude households below the $1^{\text {st }}$ percentile and above the $99^{\text {th }}$ percentile of the distribution of income. This leaves us with a sample of 2,788 households.

Based on the diaries, we also calculate households' expenditures on food and non-food consumption. The food component of expenditures consists of food purchases and selfprovisioned food. To derive a monetary value of self-provisioned food, we first calculate unit prices for all food items that are purchased in markets across various administrative levels (enumeration area, sub-district, district, province, and country) for every month of the year. The quantity of self-provisioned food is then multiplied with the unit price at the lowest level for which prices are reported from at least eight households. For food items for which very

\footnotetext{
${ }^{10}$ Following Deaton (1997), individuals aged 15 and above are considered to be adults (and assigned the factor 1), while children between 0 and 4 years of age receive the factor 0.4 and children between 5 and 14 years receive the factor 0.5.

${ }^{11}$ Skoufias et al. (2009) suggest an upper boundary of 4500 calories. However, FAO and WHO recommend $56 \mathrm{kcal}$ per kg of bodyweight per day for a vigorous or vigorously active lifestyle (FAO 2004). Therefore, we set our upper boundary at 6000 calories as bodyweights of $100 \mathrm{~kg}$ are not completely uncommon in the Mongolian population. An analysis of excluded observations indicates that over- or underreporting does not follow any discernable pattern.

${ }^{12}$ See NSO et al. (2004, p. 88-89) for details on how the Paasche price index is calculated.
} 
few households reported prices or for which reported prices showed a high spread, we rely on the quarterly food price survey that collects shop prices of various food items at the district level. The non-food component of expenditures consists of household expenses for 242 items that were recorded in the consumption diary. These include education, health, clothing, jewelry, recreation, household goods, durables, housing, transportation, and communication. The total value of household consumption expenditure is again expressed in adult equivalents, normalized per day, and adjusted for seasonal and locational price differences.

Information on durable ownership - which is used for a robustness test - is obtained from the LSMS questionnaire, which records the current monetary value of an extensive list of 47 durables that include home appliances, furniture, electronic equipment, means of transportation, jewelry, and dwelling. The total value of all items owned was aggregated into one measure. For herders, we include a separate measure of livestock holdings (i.e., the number of animals owned).

\section{Estimation strategy}

The aim of our analysis is to investigate the role of food self-provisioning for nutrient intake. As a first step, we analyze nutrient wealth elasticities across different livelihood groups that differ strongly in the extent to which they produce food within the household economy. Next, we explore in more detail the impact of the self-provisioning of food on nutrient consumption within livelihood groups. In a third step, we investigate the effect of an extreme weather event on nutrition patterns and the role of food self-provisioning.

Following standard practice in the literature on nutrition, the theoretical starting point for our investigation is household utility (e.g., Behrman et al. 1997; Pitt and Rosenzweig 1985; Rashid et al. 2011). We base our analysis on the agricultural household model taking market imperfections - mainly incomplete food markets due to remoteness - into account. Household utility is thus not only a function of the household's consumption but also of its production decision/ production factors (Singh et al. 1986).

First, we explore the heterogeneity in nutrition patterns and the nutrient wealth elasticities across different livelihoods. We employ a reduced form equation and estimate the determinants of nutrient consumption for household $i$ in province $j$ in month $k$ as follows: 
$\ln \left(\right.$ Nut $\left._{i j \mathrm{k}}\right)=\alpha_{0}+\beta_{1}$ small scale herder ${ }_{i}+\beta_{2}$ large scale herder ${ }_{i}+\beta_{3} \ln \left(\right.$ income $\left._{i}\right)+\beta_{4} X_{i}+\beta_{5} Z_{i}+$

$\alpha_{1} \ln \left(\right.$ price index $\left._{\mathrm{jk}}\right)+\alpha_{2}$ province $\mathrm{FE}_{\mathrm{j}}+\alpha_{3}$ month $\mathrm{FE}_{\mathrm{k}}+\varepsilon_{\mathrm{ijk}}$

where $N u t$ represents the natural logarithm of daily quantities consumed per adult equivalent of a given nutrient. We employ six macronutrients as outcomes (calories, carbohydrates, animal proteins, vegetable proteins, animal fats, and vegetable fats) and two micronutrients (iron and vitamin A).

We first estimate Equation 1 for the full sample of households, including two indicator variables for small-scale and large-scale herding households. We define as small-scale herders those households that own 99 or fewer animals and, thus, self-provision at least some of their consumption needs (45 percent of sample households). Large-scale herders are defined as those with a herd size of 100 animals or more (19 percent of sample households). In Mongolia, this threshold is commonly considered the minimal herd size to derive a livelihood from herding (Goodland et al. 2009). We then estimate the model separately for small-scale herders, large-scale herders, and non-herding households. This way, we analyze the link between agriculture and nutrition within relatively homogenous groups of households that share similarities in market access and market characteristics. ${ }^{13}$ In fact, there is a strong correlation between livelihood group, location, and access to (food) markets: About 88 percent of non-herding households live in Ulaanbaatar or provincial capitals (where multiple grocery stores and food markets exist) while 74 percent of large-scale herders living in the countryside (where most households live in scattered campsites and hence no markets exist). The category of small-scale herders is in-between, with about 47 percent of small-scale herders residing in provincial capitals or districts centers (which have at least one grocery shop offering a basic supply of goods) and 47 percent living in the countryside.

Income stands for the daily income per adult equivalent. As both income and outcomes are logarithmically transformed, the coefficient can be interpreted as elasticity. We prefer income over consumption expenditures to measure household wealth for two reasons: First, most rural households produce and consume their own meat and dairy products. Markets and, hence, prices for the most important food products do not exist in rural areas. Thus, assigning realistic values for food produced and consumed within pastoralist households is challenging. Moreover, the population density in Mongolia is extremely low, with about 1.58 people per

\footnotetext{
${ }^{13}$ Hoddinott et al. (2015) use a similar approach of splitting their sample of Ethiopian households by market access.
} 
square kilometer in 2002 (NSO 2003). This makes it even more difficult to derive a monetary value for food produced by pastoralists, who often have their campsites far from the nearest market. Second, there is a specific disadvantage of using food consumption expenditures as wealth measure: The outcome variable and the wealth measure would be derived from the same original survey question, which may create correlated errors and upward-biased results (e.g., Bouis and Haddad 1992). As a robustness test, we employ alternative wealth measures consumption expenditures for food and non-food items, as well as the value of durables and the number of livestock owned - and obtain similar results, as will be discussed below.

The estimation of the determinants of nutrition demand is challenged by an endogeneity problem, which is widely discussed in the literature on the subject (Bouis and Haddad 1992). Not only can household wealth influence nutrient intake but nutrition can impact household income, particularly through the wages a person can earn if he or she is in a better physical condition due to better nutrition (Strauss and Thomas 1998). In addition to this potential reverse causality, the estimated effect of wealth could be biased by an omitted variable that affects both wealth and nutrition. We address this issue by employing an instrumental variable approach as a robustness test. Household income is instrumented by the median income in the enumeration area; household total consumption expenditures are instrumented by the median non-food expenditures in the enumeration area. This choice of instruments follows the study by Skoufias et al. (2009).

We also control for production factors (vector $X$ ). This way, we account for the fact that in the presence of market imperfections, household consumption and production decisions are no longer separable (Singh et al. 1986). Most importantly, for herding households we control for the number of livestock each household owns. While the number of livestock holdings is subject to the household's decision-making, we argue that, for two reasons, livestock holdings can be considered fixed in the medium term, thus being independent of the household's food consumption decisions. First, during the socialist era, most livestock activities were organized in collective production units characterized by a very high division of labor, while households were only permitted to own a limited number of private livestock. With the beginning of the transition period in the early 1990s, cooperatives were privatized based on a voucher system with individuals given asset shares and livestock from the former cooperatives (Bedunah and Schmidt 2004; Schmidt 1995). Thus, households were allocated most of their initial animal stock only 10 years before the survey period. Second, two consecutive winter disasters in $1999 / 00$ and 2000/01 - immediately prior to our period of investigation - resulted in mass 
livestock losses, further exogenously decimating herd sizes. Furthermore, we include the distance to the nearest water source, which is relevant for both herding and farming activities given the dry climatic conditions in Mongolia. Lastly, we control for vehicle ownership and the distance to the nearest health center. ${ }^{14}$ The latter measures remoteness, indicating both the household's non-herding income generating opportunities and the degree of householdspecific market failures. For several reasons, herders' location - and hence the distance variables - can be considered exogenous (at least in the medium term). While land is state property, there are complex systems of customary rights over campsites. For instance, by investing in shelters, building up animal dung, as well as constructing and maintaining wells, herders underline their use rights over campsites. In addition, despite the extremely low population density in rural Mongolia, grazing land surrounding settlements have been overexploited (Goodland et al. 2009). Thus, conflicts between herders over good pastures that have access to fresh water and suitable campsites are common. Use rights over campsites are also passed on from generation to generation.

The vector $Z$ represents household-level controls. ${ }^{15}$ These include household size, the dependency share (the share of economically inactive household members), whether the head of household is female, age of the head, and education of the most senior woman in the household (in years). The latter reflects the predominant role mothers play in the nutrition of household members and, in particular, children (e.g., Block 2004).

Province fixed effects account for the fact that both demand and supply factors for food may differ across provinces. These include, for instance, the supply of regionally grown food products, regional consumption habits, the potential for agricultural activities (such as soil quality, vegetation, and climate) and the proximity to the capital city Ulaanbaatar, which influences both the prices and the availability of imported foods. Month fixed effects control for seasonal differences in food prices, which fluctuate considerable across the year. Also, daily calorie requirements are much higher during the extremely cold winter months,

\footnotetext{
${ }^{14}$ Both the distance to the nearest water source and the nearest health center are logarithmically transformed. Simply transforming a distance of zero $\mathrm{km}$ into a very small distance before taking the logarithm might lead to biased estimates. To avoid losing households that live directly next to a water source or health center, we follow the approach discussed by Battese (1997). Our regressions include two variables for each distance measure: D and $\log (\operatorname{distance}+\mathrm{D})$, where D is a dummy variable that takes the value of one if the household reports a distance of zero or less than two km and zero otherwise.

${ }^{15}$ We also use discriminant analysis in order to identify further control variables, given that few of the theoretically predicted covariates are statistically significant. One possible explanation is that the empirical context of our study - namely a large share of herders in the population who pursue a livelihood as nomadic pastoralists - may be rather different compared to empirical settings analyzed in the existing literature. Results from discriminant analysis pointed toward the importance of time and regional effects for making households "low consumers".
} 
particularly for herders working outdoors. A price index accounts for the province-level time trends in prices. Lastly, $\varepsilon_{i j k}$ is a random idiosyncratic error term clustered at the enumeration area level. Summary statistics of all variables used are displayed in table 1.

Second, we account in more detail for the extent of self-provisioning of food and analyze its impact on nutrient intake with the following model:

$\ln \left(\right.$ Nut $\left._{\mathrm{ijk}}\right)=\alpha_{0}+\beta_{1}$ food selfprovisioning $_{\mathrm{i}}+\beta_{2} \ln \left(\right.$ income $\left._{\mathrm{i}}\right)+\beta_{3}$ food selfprovisioning $_{\mathrm{i}} * \ln \left(\right.$ income $\left._{\mathrm{i}}\right)+$ $\beta_{4} \mathrm{X}_{\mathrm{i}}+\beta_{5} \mathrm{Z}_{\mathrm{i}}+\alpha_{1} \ln \left(\right.$ price index $\left._{\mathrm{jk}}\right)+\alpha_{2}$ province $\mathrm{F}_{\mathrm{j}}+\alpha_{3}$ month $\mathrm{FE}_{\mathrm{k}}+\varepsilon_{\mathrm{ijk}}$

The food self-provisioning vector comprises two variables. First, for herding households, we employ the share of consumed calories from meat and dairy products that a household selfprovisions through animal husbandry out of the total amount of calories consumed by the household. Second, for both herding and non-herding households, we include an indicator variable taking the value one if a household consumed any fruits, vegetables, or other selfproduced crops. ${ }^{16}$ In remote areas, the commercial supply of fresh fruits and vegetables is limited. Thus, although farming activities are mostly small scale, often consisting of backyard gardening, this may still be one way to reduce the prevalent deficiencies in vitamins and enrich the dietary diversity of households. Besides exploring the level effects of food selfprovisioning, we also interact these variables with income. This allows us to explore whether the self-provisioning of food affects the nutrient wealth elasticities.

One concern that arises in this reduced form model is that there may be unobserved factors at play that influence both the extent to which households are autarkic in their food production and the error term. We acknowledge that concerns of endogeneity (and also reversed causality) could only be fully ruled out with panel data, an instrumental variable approach, or some agricultural intervention implemented with randomization, none of which is available in this context. ${ }^{17}$ Yet, we hope to minimize concerns of endogeneity by two factors. First, we purposefully define the extent of food self-provisioning in relative terms, as share of total

\footnotetext{
${ }^{16}$ Our preferred measure is the share of calories from own farming. Unfortunately, this share was rather small (about 2 percent for the whole sample) and prone to measurement errors. As a robustness test, we employ the value of own harvest consumed by the household. All results are qualitatively similar when using this finer measure (results available upon request). Yet, given the difficulty of assigning realistic prices to the harvest, our preferred measure is the simple indicator variable for consuming any food crops from own harvest.

${ }^{17}$ We tried using remoteness as instrument for the share of food self-production. Remoteness might influence food selfprovisioning both through its effect on the household's production potential in less densely populated areas as well as through its impact on market access. However, none of the specifications fulfilled the requirements for strong instruments, so results are not reported here.
} 
calories consumed. This approach reduces the bias stemming from differences in absolute levels of nutrient intake. Second, we estimate the model separately for small-scale herders, large-scale herders, and non-herding households, assessing the effect of food selfprovisioning within each livelihood group. By definition, the self-provisioning of food differs strongly across the three livelihood groups and reflects varying market access. Moreover, by estimating the model separately for each livelihood group, we avoid modelling the decision to follow a herding livelihood - and thus self-provision meat and dairy products at all.

Third, we test whether exposure to the 2001/02 dzud influenced nutrition intake and the selfprovisioning of food among herding households. The HIES/LSMS survey questionnaire does not record household-level information on exposure to the shock. Thus, we must resort to district-level data to construct a measure of shock intensity. ${ }^{18}$ We use historic livestock census data collected by the NSO, which are available for each year from 1970 onward at the district level (with 69 districts covered by the HIES/LSMS). ${ }^{19}$ For each district, we subtract from the sheep mortality in 2002 the mean sheep mortality over the 1970-2001 period in the same district and divide the term by the standard deviation of local sheep mortality. ${ }^{20}$ By relating sheep mortality occurring during the dzud winter to the long-term local patterns in sheep mortality, we account for the experience that households gathered over time in coping with the risk of extreme weather events. The intensity index varies between -0.37 (indicating lower or "better" than average livestock mortality) and 3.59 (the most severely affected district) across survey districts. As mutton is by far the most widely consumed meat, sheep losses should capture the potential nutrition effect of the dzud most directly.

The shock measure is included as additional vector in Equation 2, with all other variables included as discussed above. The estimated coefficient of the shock measure can be interpreted as causal effect under the assumption that households did not anticipate the magnitude of livestock losses caused by the dzud. Two empirical observations speak in favor

\footnotetext{
${ }^{18}$ One potential limitation inherent in this analysis is that dzuds are a very local phenomenon and hence a district-level shock measure may be too coarse. On average, districts have an average size of 4,600 square $\mathrm{km}$ and a population of 7,200 (NSO 2003). Unfortunately, all identifying information on households' residence below the district level is removed from the survey data. Therefore, we have to work with this data limitation. The sample size is reduced by 64 households, for whom information on the district of residence is missing.

${ }^{19}$ In principle, one could also derive a measure of dzud intensity based on weather data. Yet, the dzud was caused by a combination of unfavorable weather conditions occurring over a relatively long time span, as outlined in section 2.2. Aggregating various sub-measures of climate conditions into one common index is not trivial (Tachiiri et al. 2008). In addition, researchers working on Mongolia have not reached a consensus regarding what climate variables best measure dzud intensity.

${ }^{20}$ See Groppo and Schindler (2014) for details on the construction of the index and the data source.
} 
of this assumption: First, the severity of the 2001/02 dzud was extreme. Sheep mortality in 2002 was as high as 72 percent in some survey districts. Second, the occurrence of dzuds in three consecutive winters (although not occurring in the same localities) is extremely unusual.

In addition, the shock measure is interacted with the two food self-provisioning variables. This way, we explore whether dzud exposure changes the role food self-provisioning plays for nutrient intake. However, we caution that the estimated coefficient should only be interpreted as correlation rather than causality given that households might change the amount of food self-provisioning in response to the shock but also as preemptive measure.

\section{Results}

\subsection{Nutrition patterns across livelihood groups}

Mongolian household food consumption follows distinct seasonal patterns. Figure 2 shows that caloric intake is low in spring (March-June) and highest in February and July. In these two months the two main Mongolian festivities take place, the Mongolian New Year Tsagansaar and the mid-summer national festival Naadam. Even though this trend is visible across all groups of households, the seasonal variation in food consumption is most pronounced among the group of large-scale herding households and least pronounced for nonherding households. One possible explanation is that cultural festivities - where special food is prepared in large quantities and relatives and friends pay each other visits - play a more important role in the lives of herders compared to other groups of households. Such festivities are among the few occasions where nomadic households (which otherwise have their campsites dispersed across the vast countryside) meet each other. Festivities are thus a welcome occasion for social networking and distraction. In a context characterized by unpredictable weather conditions and lack of formal insurance markets, festivities may also serve an important economic function in renewing informal risk sharing networks.

Table 2 provides unconditional statistics on the availability and adequacy ratios of various nutrients across livelihood groups. The overall energy intake for small-scale and large-scale herders is 2,270 and 2,580 calories per day per adult equivalent, respectively. This corresponds closely to the recommended energy intake in Mongolia. In contrast, the calories consumption of non-herding households is much lower: Those households consume an average of 2,000 calories per day per adult equivalent, which corresponds to an adequacy 
ratio of only 80 percent. Table 2 also shows that adequacy ratios diverge even more across livelihood groups for nutrients stemming from animal sources. Herding households with small and large herds consume about 95 and 139 percent of the recommended quantity of animal proteins, respectively. Both types of herding households consume more than twice the recommended amount of animal fats. In contrast, for non-herding households, the adequacy ratio in animal proteins is only 46 percent, an alarmingly low level. This pattern is inversed for vegetal fat intake, which is much higher for non-herding households (but still only half of the recommended level). Vegetal fat is the nutrient that shows the greatest deficiencies for herders, with adequacy ratios of only 28 to 36 percent.

Next, we estimate the nutrition provision function (Equation 1) for eight different nutrients in a multivariate regression (Table 4). Results show that both types of herding households consume significantly more calories, carbohydrates, nutrients from animal sources, iron, and vitamin A per day per adult equivalent than non-herding households, holding all other factors constant. The estimated effects are also economically large. For instance, herders with small and large herds consume about 10.0 percent and 20.6 percent more calories and 9.5 percent and 18.6 percent more iron, respectively, than do non-herding households. The estimated coefficients are statistically significant at the 1 percent level. Although the energy needs of herders are higher due to their strenuous work outside, these households are also able to consume more of the other nutrients studied than basic needs call for, thus making their overall nutritional situation appear better than that of non-herding households. Yet, it is not only nutrient intake and the amount of self-provisioned food per se that differs across livelihood groups. Various household and environmental characteristics have a differential impact on nutrition for households following different livelihoods. Therefore, in the following, all regressions are estimated separately for each of the three livelihood groups.

As a next step, we explore the nutrient income elasticities across livelihoods (Table 5). ${ }^{21}$ Results are now presented separately for small-scale herders (Panel A), large-scale herders (Panel B), and non-herding households (Panel C). All of the estimated nutrient income elasticities are positive and of comparable magnitude with previous studies (e.g., Pitt et al. 1990; Skoufias et al. 2011). Two findings are noteworthy: First, income has a surprisingly homogeneous effect on nutrient intake across different livelihood groups. For instance, the

\footnotetext{
${ }^{21}$ As total income also includes income from herding activities, we might encounter collinearity problems as we also control for the household's number of livestock holdings. Therefore we also estimate the nutrient-income elasticity with only nonagricultural income. All results are very similar to the ones from the regressions with total income.
} 
income elasticities of calorie intake range from 0.15 for herders to 0.18 for non-herders, with the difference between them not statistically significant. Thus, it appears that short-term fluctuations in household income have a very similar effect on food consumption among herding households that derive a share of the consumption needs through own herding activities and among non-herding households that buy almost all food in the market. In turn, this could suggest that non-herding households are not, per se, more vulnerable to fluctuations in food prices

Second, vegetal fat, animal fat, and vitamin A intake have the highest income elasticities (irrespective of the livelihood group), similar to the findings of Skoufias et al. (2009) in Mexico. Thus, the consumption of vegetal fat, animal fat, and vitamin A responds more strongly than other nutrients to short-term income fluctuations. This indicates that households may substitute food items in times of stress to keep overall energy intake constant. Such substitution could occur both within food groups ${ }^{22}$ - for example, by replacing meat with less expensive (and less rich in fat) animal interior - and across food groups. A number of nonmeat food items (such as beans) provide the same amount of energy at lower prices.

As robustness test, we estimate the nutrition provision function (Equation 1) separately for two alternative wealth measures (consumption expenditures and assets). ${ }^{23}$ Results are in line with our findings for the nutrient-income elasticities: All of the estimated nutrient wealth elasticities are positive and almost all are statistically significant. When comparing the various nutrient wealth elasticities, we find that the consumption expenditure elasticities are much higher than the income elasticities for nutrient intake. This result holds for all three types of households studied and for all eight nutrients. This could suggest that households are relatively well equipped to cushion short-term income fluctuations, while their nutrient intake responds more strongly to changes in permanent income. ${ }^{24}$

\footnotetext{
${ }^{22}$ See Skoufias et al. (2009) and Pitt and Rosenzweig (1985) for an in-depth discussion.

${ }^{23}$ Each of the elasticities displayed is obtained from a separate regression that includes the complete set of socio-economic controls as well as province and month fixed effects as used in Table 4.

${ }^{24}$ Yet, the estimated low elasticities of durables contradict this interpretation (with the calorie durables elasticities ranging between 0.02 and 0.06). One would expect household durables to be a valid indicator of long-term income and thus their elasticities should be higher. Nevertheless, the finding of low durables elasticities could be due to the specific Mongolian context: On the one hand, nomadic households possess relatively few assets; on the other hand, the process of transition toward a market economy that started some 10 years prior to the data collection was not yet complere. Therefore, we argue that in 2002 - when the data analyzed here were collected - asset holdings do not reflect permanent income of households well.
} 
Furthermore, OLS and IV approaches yield very similar results for the nutrient elasticity of income and consumption expenditures, both in terms of the level of significance and the magnitude of the estimated elasticity. This holds for all nutrients and for all three groups of households. Therefore, we are confident that our results are not driven by endogeneity and omitted variable problems. ${ }^{25}$

\subsection{Accounting for the amount of food self-provisioning}

In this section, we exploit differences in the extent of food self-provisioning within livelihood groups and investigate its impact on the intake of nutrients. Descriptive statistics show large differences between the three groups of households in terms of the extent of self-production of food (Table 3). About 14 percent of both small-scale and large-scale herders cultivate food crops, compared to only 4 percent of non-herding households. Small-scale and large-scale herders provision between 21 and 35 percent of the calories consumed within the household through animal husbandry, respectively. Large-scale herders are close to self-sufficient in meat and dairy products (producing 86 and 72 percent of the consumed calories of meat and dairy products, respectively), while small-scale herders produce about half of the consumed meat and dairy products within the household economy. ${ }^{26}$ In turn, the quantity of meat consumed varies across livelihood groups: non-herding households, small-scale herders and large-scale herders derive on average 14, 20 and 25 percent, respectively, of their calories from meat. These unconditional statistics point toward some overall effect of food selfprovisioning on the consumption of nutrients, which we investigate in greater detail in a multivariate framework below. The three livelihood groups also face different price levels. While prices paid per kilogram of flour are similar, non-herders pay 6 percent and large-scale herders almost 14 percent more per kilogram of carrots than small-scale herders. This is likely to be a result of differences in market access as well as in the costs for transporting vegetables from their production sites to markets in province centers or the capital city.

Next, we estimate the effect of food self-provisioning on nutrient intake using a multivariate regression (Table 6). Results indicate that food self-provisioning has a significant impact on the amount of different nutrients consumed for both small-scale and large-scale herders. This effect is most pronounced for small-scale herding households (Panel A) that derive their

\footnotetext{
${ }^{25}$ Based on this finding, as well as the comparability of elasticities of the different wealth measures discussed above, we only present results for income in the subsequent analyses. Results for the other wealth measures are available upon request.

${ }^{26}$ The category "meat" includes sausages and canned meat, which are always bought in stores.
} 
sustenance from multiple sources. For those households, consuming crops from own farming has a statistically significant and positive effect on the intake of calories, carbohydrates, and nutrients from vegetal sources. For instance, small-scale herding households that do farming activities consume an average of 6 percent more calories per day per adult equivalent than small-scale herding households that do not farm. The magnitude of the effect of food selfprovisioning through farming is particularly large for vegetal fats - for which small-scale herding households exhibit the largest deficiencies.

In contrast, the provision of meat and dairy products through the household's animal husbandry activities has ambivalent effects on the household's diet. On the one hand, the share of calories from own animal husbandry is significantly and positively related to the intake of calories. ${ }^{27}$ For instance, for large-scale herders with average income, increasing the share of calories from own production by one percentage point is associated with a 0.39 percent higher calorie intake (Table 6, Panel B). The intake of vitamin A and nutrients from animal sources responds disproportionately to an increase in the share of selfprovisioned food. For both types of herding households with average income, a one percentage point increase in the share of calories from own production is associated with a 2.5 percent increase in the intake of animal fat. On the other hand, the share of food consumed from own meat and dairy production significantly decreases the intake of carbohydrates and nutrients from vegetal sources. The effect is economically large: For small-scale herders with mean income, increasing the share of self-provisioned calories from own animal husbandry by one percentage point reduces the intake of vegetal fat by 1.43 percent. Farming only partly counteracts this effect. Thus, food self-provisioning seems to entail substitution effects that change the composition of the household's diet. In particular, a higher share of calories from own animal husbandry is associated with a higher specialization in the consumption of meat and in turn with a worsened nutritional situation for nutrients from vegetal sources for which households exhibit already the greatest deficiencies.

Interestingly, the self-provisioning of food also influences some of the nutrient income elasticities. For instance, for small-scale herding households (Table 6, Panel A), the interaction term between income and the share of calories from own animal husbandry is statistically significant and negative for animal fat and vitamin A. Thus, for small-scale

\footnotetext{
${ }^{27}$ As robustness test, we also estimate Equation 2 with the share of calories consumed from own meat and dairy production transformed into a binary variable. All results described here still hold, irrespective of whether the cutoff is set at 25,30 or 35 percent of calorie consumption from own production.
} 
herders producing a relatively large share of calories within the household, the intake of those nutrients is less dependent on short-term fluctuations in income compared to small-scale herders that buy most of their food in the market. We obtain similar results for the income elasticities of calories, carbohydrates, nutrients from vegetal sources, iron, and vitamin A for non-herding households that farm (Panel C). For all of those nutrients, consuming crops from own farming reduces the income elasticity of nutrient intake. In contrast, for herding households with large herds, the self-provisioning of food does not influence the nutrient wealth elasticities. Thus, it seems that the self-provisioning of food stabilizes consumption patterns for small-scale herders and non-herding households, both of which produce only minor shares of their food within the household.

Following de Janvry et al. (1991) and Villa at al. (2011), our results might also be interpreted as an empirical test of market failures in local meat markets. As Villa et al. (2011) point out, "increases in household production of those goods [for which market failures exist] would increase consumption of just those goods, but have little to no impact on other household consumption goods" (p. 345). In fact, in the context of Mongolian herders, we not only observe the absence of positive effects of meat self-production on other food groups, but even a negative effect on the intake of other food groups. One possible explanation is that herding households that are highly self-sufficient in meat reside in remote rural areas that render transportation costs to the next district center costly. Thus, there may be household-specific market failures for other food items, including perishable vegetables. To further explore this channel, we interact remoteness - measured by the distance to the next health center - with the food self-provisioning variables (results available upon request). Interestingly, the negative effect of the share of calories consumed from own meat and dairy production on the intake of carbohydrates and nutrients from vegetal sources is no longer significant for largescale herders that reside in the proximity of a health center and, thus, have better market access. Thus, household-specific market failures seem to exist for households living in remote areas. The self-provisioning of food could be, to some extent, a substitute for market access.

\subsection{Impact of the 2001/02 dzud on nutrition}

Last, we test whether the extremely severe winter of 2001/02 influenced food consumption and the self-provisioning of food among herding households. An unconditional comparison of average energy intake of households living in districts with high and low shock intensity (above and below the $80^{\text {th }}$ percentile of the distribution of standardized sheep mortality) does 
not show systematic patterns: Against our expectations, calorie intake is not systematically lower in severely affected districts. This finding is also obtained when using different thresholds $\left(85^{\text {th }}\right.$ or $90^{\text {th }}$ percentile) to define severely affected districts. In contrast, total real consumption expenditures of both types of herding households get significantly lower in the second half of the year in districts with high shock intensity. This could suggest that exposure to the dzud leads to a longer-term reduction in consumption.

Table 7 displays the estimated coefficient of the shock intensity measure (standardized sheep mortality in 2002) obtained from estimating an extended version of Equation 2 with OLS. Note that this specification also includes month and province fixed effects, income, and the complete set of socio-economic controls as discussed above. ${ }^{28}$ We do not find evidence for a significantly negative effect of the dzud on the intake of calories. This holds for both smallscale and large-scale herding households. This finding fits well with the results of two other studies on dzud in Mongolia by Bolormaa et al. (2003) and Siurua and Swift (2002). ${ }^{29}$ Both studies find that households were able to maintain their energy intake, despite the severe damages caused by the dzud.

However, for both small-scale and large-scale herders, the 2001/02 dzud had a significant and negative effect on the consumption of animal fat. A one standard deviation increase in dzud intensity decreases the intake of animal fat by 12.8 percent for small-scale herding households with an average share of food self-provisioning. This could indicate that in times of stress, households with small-scale livestock activities substitute away from the consumption of livestock products in order to not deplete their herd further.

Exposure to the shock also significantly affects the food self-provisioning-nutrition nexus. Again, this result is much more pronounced for small-scale herders. The interaction term between sheep losses and the share of calories from own animal husbandry is statistically significant for calories, carbohydrates, animal proteins, and vitamin A. Thus, for small-scale herders living in severely affected districts, the effect of food self-provisioning on the intake of calories, animal proteins, and vitamin A remains positive but is smaller in magnitude compared to small-scale herders living in unaffected districts. In contrast, the negative effect

\footnotetext{
${ }^{28}$ The magnitude and level of significance of these variables remain very similar after the inclusion of the shock measure.

${ }^{29}$ The database of the Bolormaa et al. (2003) study is a (non-representative) survey implemented in 2001 of children and mothers living in districts that were either severely affected or non-affected by the dzud of 2000/01. Siurua and Swift (2002) conducted in-depth qualitative interviews with 14 herding households in the province of Bayankhongor in 2002.
} 
food self-provisioning has on the household's carbohydrate consumption is stronger in dzudaffected areas than unaffected areas. Overall, these correlations between shock intensity and food self-provisioning are only observable for the self-provisioning of meat and dairy products, but not for non-meat agricultural products. This suggests that the potential dzud effect manifests itself through household-level livestock losses.

\section{Discussion}

In this paper, we use nationally representative household survey data from 2002/03 to investigate the role of food self-provisioning for the nutrient consumption of households in Mongolia. The data entail exceptionally detailed information on households' food consumption, which were recorded with consumption diaries over a period of 12 weeks for each household. The outcomes of interest are the daily quantities consumed per adult equivalent of six macronutrients (calories, carbohydrates, animal proteins, vegetable proteins, animal fats, and vegetable fats) and two micronutrients (iron and vitamin A). Our analysis distinguishes between the three prevalent Mongolian livelihoods: urban wage employees, rural households with small-scale animal husbandry activities, and pastoralist households owning large herds. Those three livelihood groups derive food from different sources: in urban areas, food is mostly obtained from shops and markets, while in rural areas, households produce almost all of their own dairy products and meat. The three livelihood groups also face different degrees of market imperfections for food and agricultural output that range from being close to perfect in urban areas to completely missing for some food groups in remote rural areas.

Results show that food consumption patterns differ significantly across the three livelihoods. We find that both small-scale and large-scale herding households consume significantly more of each nutrient than non-herding households. This suggests a better overall nutrition situation of herding households than non-herding households, which cannot solely be attributed to different consumption needs due to different physical activity patterns. The wealth elasticity of nutrient intake is almost always statistically significant, positive, and remarkably similar across livelihood groups. The estimated elasticities for calories range between 0.15 to 0.18 for income, 0.36 to 0.43 for consumption expenditures, and amount to 0.03 for durables. An instrumental variables approach yields very similar estimates for both instrumented income and instrumented consumption expenditures, suggesting that results are not driven by reverse causality or correlated measurement errors. 
Farming food crops improves the nutritional situation of small-scale herders. Their intake of calories and nutrients from vegetal sources is increased if they pursue small-scale agricultural production. In contrast, the provision of meat and dairy products through animal husbandry activities has ambivalent effects on the household's diet. On the one hand, the share of calories from own animal husbandry has a significantly positive effect on the intake of calories, vitamin A, and nutrients from animal sources of both small-scale and large-scale herding households. Another positive aspect of food self-provisioning is that it significantly reduces income nutrient elasticities among small-scale herders and non-herding households. In other words, for households that produce a small share of the food within the household, food self-provisioning makes food consumption patterns less dependent on short-term fluctuations in income. On the other hand, the share of food consumed from own meat and dairy production significantly decreases the intake of carbohydrates and nutrients from vegetal sources among herders. Thus, food self-provisioning seems to entail substitution effects that change the composition of the household's diet and in turn worsen the nutritional situation for those nutrients for which households already exhibit the greatest deficiencies. We interpret this finding in light of household-specific market failures caused by remoteness, which renders transportation costs to the next market prohibitively expensive.

In contrast to expectations, exposure to a severe shock - the extremely harsh 2001/02 winter that caused mass livestock death - does not reduce household calorie consumption. However, exposure to the shock significantly reduces the intake of animal fat for both types of herding households. The food self-provisioning-nutrition nexus also changes with dzud exposure: In dzud-affected areas, the positive effect of food self-provisioning on the intake of calories, animal protein and vitamin $\mathrm{A}$ is smaller compared to less exposed areas for small-scale herding households. This provides evidence for the hypothesis that households employ substitution strategies to keep overall energy intake constant.

Several policy implications can be drawn from our results. First, to improve the nutritional situation of the population, flexible policy is needed to cater for diverse livelihoods that follow distinct food consumption patterns and, therefore, differ substantially in their nutrient adequacy ratios. Second, in rural areas, shortages in the supply of fresh foods appear to be prevalent. Small-scale farming seems to be a potentially effective channel to ameliorate the prevalent low adequacy ratios in the consumption of vegetal fats among the rural population. Moreover, enhancing the supply of foods that cannot be produced in the local climatic conditions is an area for policy interventions. Third, income elasticities are highest for 
vitamin A (0.12 to 0.36$)$ and vegetal fat $(0.30)$, for which both herding and non-herding households have the lowest adequacy ratios. This suggests that income transfers could potentially improve the dietary quality of Mongolian households. 


\section{References}

Arlappa, N., K. Venkaiah, and G.N.V. Brahmam (2011). Severe drought and the vitamin A status of rural pre-school children in India. Disasters 35 (3), 577-586.

Arndt, C., M.A. Hussain, and L.P. Østerdal3 (2012). Effects of Food Price Shocks on Child Malnutrition: The Mozambican Experience 2008/09. UNU-WIDER Working Paper 2012/89.

Azzarri, C., A. Zezza, B. Haile, and E. Cross (2015). Does Livestock Ownership Affect Animal Source Foods Consumption and Child Nutritional Status? Evidence from Rural Uganda. Journal of Development Studies 51 (8), 1034-1059.

Batima, P. (2006). Climate Change Vulnerability and Adaptation in the Livestock Sector of Mongolia. Washington, DC: International START Secretariat.

Battese, G.E. (1997). A note on the estimation of Cobb-Douglas production functions when some explanatory variables have zero values. Journal of Agricultural Economics 48 (1-3), 250-252.

Bedunah, D.J. and S.M. Schmidt (2004). Pastoralism and Protected Area Management in Mongolia's Gobi Gurvansaikhan National Park. Development \& Change 35 (1), 167-191.

Behrman, J.R., A.D. Foster, and M.R. Rosenzweig (1997). The dynamics of agricultural production and the calorie-income relationship: Evidence from Pakistan. Journal of Econometrics 77 (1), 187-207.

Block, S.A. (2004). Maternal Nutrition Knowledge and the Demand for Micronutrient-Rich Foods: Evidence from Indonesia. The Journal of Development Studies 40 (6), 82-105.

Bolormaa, N., B. Byambatogtoch, J. Bates, M.K. Serdula, R. Kaufmann, B.A. Woodruff, L.K. Khan, and C. Gillespie (2003). Final report of a survey assessing the nutritional consequences of the Dzud in Mongolia. Ulaanbaatar: Nutrition Research Center, World Health Organization, UNICEF, US Centers for Disease Control and Prevention.

Bouis, H.E. and L.J. Haddad (1992). Are estimates of calorie-income fxelasticities too high?: A recalibration of the plausible range. Journal of Development Economics 39 (2), 333-364.

Carletto, G., M. Ruel, P. Winters, and A. Zezza (2015). Farm-Level Pathways to Improved Nutritional Status: Introduction to the Special Issue. Journal of Development Studies 51 (8), 945-957.

D'Souza, A. and D. Jolliffe (2014). Food Insecurity in Vulnerable Populations: Coping with Food Price Shocks in Afghanistan. American Journal of Agricultural Economics 96 (3), 790812.

de Janvry, A., M. Fafchamps, and E. Sadoulet (1991). Peasant Household Behavior with Missing Markets: Some Paradoxes Explained. Economic Journal 49 (101), 1400-1417.

De Onis, M., M. Blössner, and E. Borghi (2012). Prevalence and trends of stunting among pre-school children, 1990-2020. Public Health Nutrition 15 (1), 142-148. 
Deaton, A. (1997). The Analysis of Household Surveys: A Microeconometric Approach to Development Policy. Washington, DC: World Bank.

Ersado, L., H. Alderman, and J. Alwang (2003). Changes in Consumption and Savings Behavior before and after Economic Shocks: Evidence from Zimbabwe. Economic Development and Cultural Change 52 (1), 187-215.

FAO (2004). Human energy requirements: Report of a Joint FAO/WHO/UNU Expert Consultation. Rome: Food and Agriculture Organization of the United Nations.

FAO, IFAD, and WFP (2015). The State of Food Insecurity in the World 2015. Meeting the 2015 international hunger targets: taking stock of uneven progress. Rome: FAO.

Gibson, J. and S. Rozelle (2002). How Elastic is Calorie Demand? Parametric, Nonparametric, and Semiparametric Results for Urban Papua New Guinea. The Journal of Development Studies 38 (6), 23-46.

Goodland, A., D. Sheehy, and T. Shine (2009). Mongolia: Livestock Sector Study, Volume ISynthesis Report. Washington, DC: World Bank.

Grantham-McGregor, S.M., L.C. Fernald, and K. Sethuraman (1999). Effects of Health and Nutrition on Cognitive and Behavioural Development in Children in the First Three Years of Life. Part 2. Infections and Micronutrient Deficiencies: Iodine, Iron and Zinc. Food and Nutrition Bulletin 20 (1), 76-99.

Groppo, V. and K. Schindler (2014). Extreme Weather Events and Child Height: Evidence from Mongolia. DIW Discussion Paper 1403.

Haddad, L.J. (2013). From nutrition plus to nutrition driven: How to realize the elusive potential of agriculture for nutrition? Food and Nutrition Bulletin 34 (1), 39-44.

Hoddinott, J. (2006). Shocks and their Consequences Across and Within Households in Rural Zimbabwe. Journal of Development Studies 42 (2), 301-321.

Hoddinott, J., D. Headey, and M. Dereje (2015). Cows, Missing Milk Markets, and Nutrition in Rural Ethiopia. Journal of Development Studies 51 (8), 958-975.

IPCC (2012). Managing the Risks of Extreme Events and Disasters to Advance Climate Change Adaptation. A Special Report of Working Groups I and II of the Intergovernmental Panel on Climate Change [Field, C.B., V. Barros, T.F. Stocker, D. Qin, D.J. Dokken, K.L. Ebi, M.D. Mastrandrea, K.J. Mach, G.-K. Plattner, S.K. Allen, M. Tignor, and P.M. Midgley (Eds.)]. Cambridge, UK and New York, USA: Cambridge University Press.

Jensen, R.T. and N.H. Miller (2008). The impact of food price increases on caloric intake in China. Agricultural Economics 39, supplement 465-476.

Kachondham, Y., S. Dhanamitta, M. Oyunbileg, and L. Brown (1992). Child Health and Nutritional Status in Ulaanbaatar, Mongolia: A Preliminary Assessment. Asia-Pacific Journal of Public Health 6 (4), 226-232.

Kumar, N., J. Harris, and R. Rawat (2015). If They Grow It, Will They Eat and Grow? Evidence from Zambia on Agricultural Diversity and Child Undernutrition. Journal of Development Studies 51 (8), 1060-1077. 
Lander, R.L., T. Enkhjargal, J. Batjargal, K.B. Bailey, S. Diouf, T.J. Green, C.M. Skeaff, and R.S. Gibson (2008). Multiple micronutrient deficiencies persist during early childhood in Mongolia. Asia Pacific Journal of Clinical Nutrition 17 (3), 429-440.

Mahul, O. and J. Skees (2007). Managing Agricultural Risk at the Country Level: The Case of Index-Based Livestock Insurance in Mongolia. World Bank Policy Research Paper 4325.

Muller, C. (2009). Do agricultural outputs of partly autarkic peasants affect their health and nutrition? Evidence from Rwanda. Food Policy 34 (2), 166-175.

Murphy, D.J. (2011). Going on Otor: Disaster, Mobility, and the Political Ecology of Vulnerability in Uguumur, Mongolia. PhD Dissertation, Department of Anthropology, University of Kentucky.

National Statistical Office and UNICEF (2007). Mongolia Child and Development 2005 Survey (Multiple Indicator Cluster Survey 3): Final Report. Ulaanbaatar: National Statistical Office.

National Statistical Office of Mongolia (2003). Mongolian National Statistical Yearbook 2002. Ulaanbaatar: NSO.

National Statistical Office of Mongolia, World Bank, and UNDP Mongolia (2004). Main Report of 'Household Income and Expenditure Survey / Living Standards Measurement Survey', 2002-2003. Ulaanbaatar: National Statistical Office.

Pitt, M.M. and M.R. Rosenzweig (1985). Health and Nutrient Consumption across and within Farm Households. Review of Economics and Statistics 67 (2), 212-223.

Pitt, M.M., M.R. Rosenzweig, and H. Md. Nazmul (1990). Productivity, Health, and Inequality in the Intrahousehold Distribution of Food in Low-Income Countries. The American Economic Review 80 (5), 1139-1156.

Public Health Institute, Mongolian Ministry of Health, and UNICEF (2006). Nutritional Status of Mongolian Children and Women: Third National Nutrition Survey Report. Ulan Bator: Mongolian Ministry of Health.

Rashid, D.A., L.C. Smith, and T. Rahman (2011). Determinants of Dietary Quality: Evidence from Bangladesh. World Development 39 (12), 2221-2231.

Ruel, M.T., H. Alderman, and the Maternal and Child Nutrition Study Group (2013). Nutrition-sensitive interventions and programmes: how can they help to accelerate progress in improving maternal and child nutrition? The Lancet 382 (9891), 536-551.

Schmidt, S. (1995). Mongolia in Transition: The Impact of Privatization on Rural Life. Saarbrücken: Verlag für Entwicklungspolitik Saarbrücken.

Shively, G. and C. Sununtnasuk (2015). Agricultural Diversity and Child Stunting in Nepal. Journal of Development Studies 51 (8), 1078-1096.

Singh, I., L. Squire, and J. Strauss (1986). Agricultural Household Models: Extensions, Applications, and Policy. Baltimore: Johns Hopkins University Press. 
Siurua, H. and J. Swift (2002). Drought and Zud but No Famine (Yet) in the Mongolian Herding Economy. IDS Bulletin 33 (10), 88-97.

Skees, J. and A. Enkh-Amgalan (2002). Examining the Feasibility of Livestock Insurance in Mongolia. World Bank Policy Research Paper 2886.

Skoufias, E., V. Di Maro, T. González-Cossío, and S.R. Ramirez (2011). Food quality, calories and household income. Applied Economics 43 (28), 4331-4342.

Skoufias, E., V. Di Maro, T. González-Cossío, and S.R. Ramírez (2009). Nutrient consumption and household income in rural Mexico. Agricultural Economics 40 (6), 657-675.

Slavchevska, V. (2015). Agricultural Production and the Nutritional Status of Family Members in Tanzania. Journal of Development Studies 51 (8), 1016-1033.

Strauss, J. and D. Thomas (1995). Chapter 34: Human resources: Empirical modeling of household and family decisions. Pp. 1883-2023 in Handbook of Development Economics, edited by B. Jere and T.N. Srinivasan: Elsevier.

- (1998). Health, Nutrition, and Economic Development. Journal of Economic Literature 36 (2), 766-817.

Tachiiri, K., M. Shinoda, B. Klinkenberg, and Y. Morinaga (2008). Assessing Mongolian snow disaster risk using livestock and satellite data. Journal of Arid Environments 72 (12), 2251-2263.

Tasciotti, L. and N. Wagner (2015). Urban Agriculture and Dietary Diversity: Empirical Evidence from Tanzania. Eur J Dev Res 27 (5), 631-649.

Tserennadmid, A. (2011). Nutrient consumption and poverty in Mongolia. University of Tsukuba.

Victora, C.G., L. Adair, C. Fall, P.C. Hallal, R. Martorell, L. Richter, and H.S. Sachdev (2008). Maternal and child undernutrition: consequences for adult health and human capital. The Lancet 371 (9609), 340-357.

Villa, K.M., C.B. Barrett, and D.R. Just (2011). Differential Nutritional Responses across Various Income Sources Among East African Pastoralists: Intrahousehold Effects, Missing Markets and Mental Accounting. Journal of African Economies 20 (2), 341-375.

Welthungerhilfe, IFPRI, and Concern Worldwide (2014). Global Hunger Index 2014: The Challenge of Hidden Hunger. Bonn, Washington D.C., Dublin: Welthungerhilfe, IFPRI, Concern Worldwide.

World Bank (2006a). Mongolia Poverty Assessment. Ulaanbaatar: World Bank.

- (2006b). Repositioning Nutrition as Central to Development: A Strategy for Large Scale Action. Washington, DC: World Bank.

Zimmerman, F.J. and M.R. Carter (2003). Asset smoothing, consumption smoothing and the reproduction of inequality under risk and subsistence constraints. Journal of Development Economics 71 (2), 233-260. 
Figures and tables

Figure 1: Livestock losses in Mongolia, 1970-2003

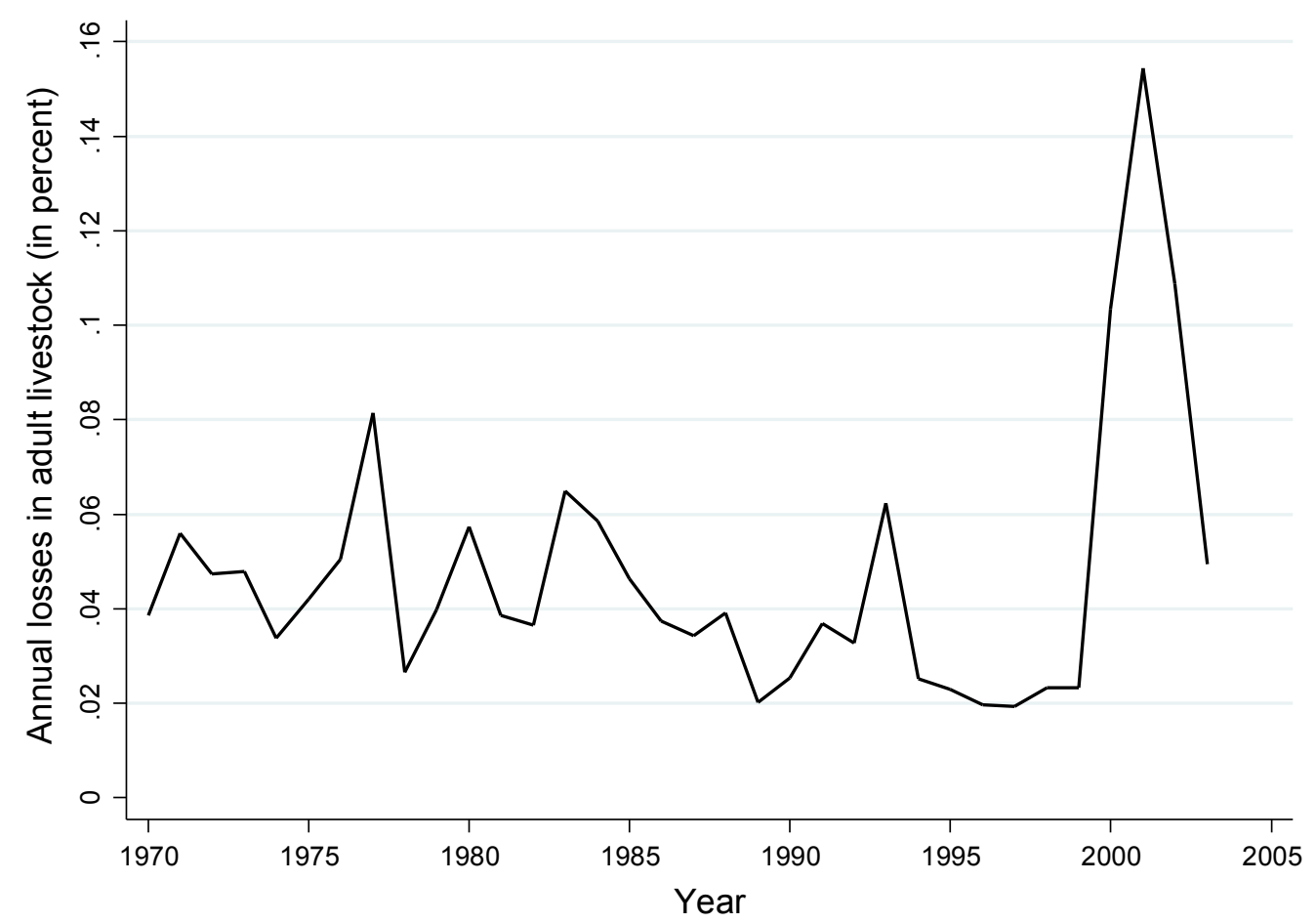

Source: Mongolia Livestock Census. 
Figure 2: Seasonal variation in calorie intake

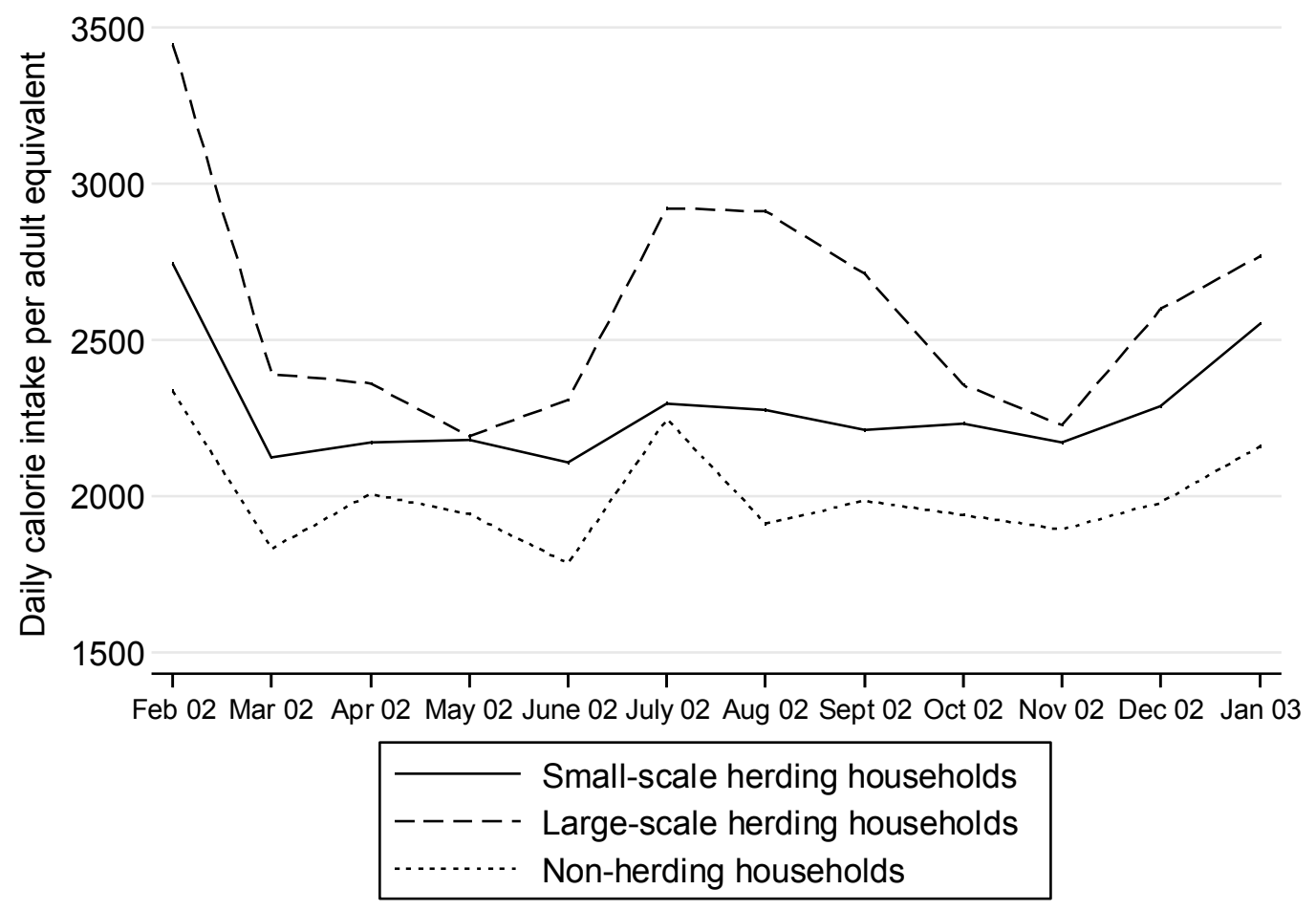

Note: Displayed is the median calorie intake per day per adult equivalent for each month between February 2002 and January 2003. Source: HIES/LSMS 2002/2003. 
Table 1: Summary statistics

\begin{tabular}{|c|c|c|c|c|c|}
\hline & Mean & $\mathrm{SD}$ & Min & Max & $\begin{array}{l}\text { Number of } \\
\text { households }\end{array}$ \\
\hline \multicolumn{6}{|l|}{ Dependent variables } \\
\hline Calories & 2,189 & 983.68 & 500.93 & 5,994 & 2,788 \\
\hline Carbohydrates & 315.68 & 137.29 & 26.16 & 1,045 & 2,788 \\
\hline Animal proteins & 46.02 & 42.58 & 0 & 422.90 & 2,788 \\
\hline Vegatal proteins & 42.62 & 18.97 & 0 & 146.77 & 2,788 \\
\hline Animal fat & 44.88 & 38.95 & 0 & 302.96 & 2,788 \\
\hline Vegatal fat & 16.64 & 13.60 & 0 & 136.03 & 2,788 \\
\hline Iron & 19.14 & 10.75 & 2.47 & 129.01 & 2,788 \\
\hline Vitamin A & 1.25 & 1.75 & 0 & 37.79 & 2,788 \\
\hline \multicolumn{6}{|l|}{ Livelihood groups } \\
\hline Small-scale herding household (1-99 livestock) & 0.45 & 0.50 & 0 & 1 & 2,788 \\
\hline Large-scale herding household (100 and more livestock) & 0.19 & 0.39 & 0 & 1 & 2,788 \\
\hline Non-herding household & 0.36 & 0.48 & 0 & 1 & 2,788 \\
\hline \multicolumn{6}{|l|}{ Wealth } \\
\hline Income per adult equivalent per month (in 1,000 MNT) & 26.31 & 30.20 & 1.02 & 671.33 & 2,788 \\
\hline Consumption expend. per adult equivalent per month (in 1,000 MNT) & 27.46 & 21.12 & 4.75 & 162.41 & 2,788 \\
\hline Value of durables per adult equivalent (in 1,000 MNT) & 1,278 & 2,122 & 10.29 & 27,619 & 2,788 \\
\hline \multicolumn{6}{|l|}{ Food self-provisioning } \\
\hline Share of calories from own animal husbandry & 0.15 & 0.19 & 0 & 0.88 & 2,788 \\
\hline Consumed crops from own farming & 0.17 & 0.37 & 0 & 1 & 2,788 \\
\hline \multicolumn{6}{|l|}{ Production and market access } \\
\hline Distance to the nearest water source & 0.85 & 1.96 & 0 & 30 & 2,788 \\
\hline Number of livestock ${ }^{\mathrm{a}}$ & 58.87 & 98.46 & 0 & 1,747 & 2,788 \\
\hline Distance to the nearest health center & 6.19 & 12.07 & 0 & 140 & 2,788 \\
\hline Vehicle ownership & 0.31 & 0.46 & 0 & 1 & 2,788 \\
\hline \multicolumn{6}{|l|}{ Socio-demographic characteristics } \\
\hline Household size & 5.25 & 1.92 & 1 & 15 & 2,788 \\
\hline Share of children under the age of 6 in the household & 0.10 & 0.14 & 0 & 0.67 & 2,788 \\
\hline Female household head & 0.13 & 0.33 & 0 & 1 & 2,788 \\
\hline Education of most senior woman (in years) & 9.86 & 3.26 & 1 & 23 & 2,788 \\
\hline Age of household head & 44.53 & 12.56 & 15 & 92 & 2,788 \\
\hline Ulaanbaatar or provincial capital & 0.56 & 0.50 & 0 & 1 & 2,788 \\
\hline District center & 0.16 & 0.37 & 0 & 1 & 2,788 \\
\hline Rural & 0.28 & 0.45 & 0 & 1 & 2,788 \\
\hline \multicolumn{6}{|l|}{ Prices } \\
\hline Price index (monthly, at province level) & 172.71 & 45.07 & 107.5 & 242.3 & 2,788 \\
\hline \multicolumn{6}{|l|}{ Shock measure } \\
\hline Standardized sheep mortality per district in 2002 & 0.33 & 0.85 & -0.37 & 3.59 & 1,720 \\
\hline
\end{tabular}

Notes: In 2002, 1,000 Mongolian Tugrik (MNT) were worth 0.89 USD. a. In the multivariate analyses below, this variable is expressed in adult equivalent terms. For each household, two months of data from consumption diaries are used. Observations from February, April, July and October are excluded. Source: HIES/LSMS 2002/2003. 
Table 2: Availability and adequacy of nutrient intake (per adult equivalent per day)

\begin{tabular}{|c|c|c|c|c|c|c|}
\hline & \multirow{2}{*}{\multicolumn{2}{|c|}{$\begin{array}{c}\text { Small-scale herding } \\
\text { households } \\
\mathrm{N}=1,332\end{array}$}} & \multirow{2}{*}{\multicolumn{2}{|c|}{$\begin{array}{c}\text { Large-scale herding } \\
\text { households } \\
\mathrm{N}=449\end{array}$}} & \multirow{2}{*}{\multicolumn{2}{|c|}{$\begin{array}{c}\text { Non-herding households } \\
\qquad \mathrm{N}=1,007\end{array}$}} \\
\hline & & & & & & \\
\hline & Availability & $\begin{array}{l}\text { Adequacy } \\
\text { ratio }\end{array}$ & Availability & $\begin{array}{l}\text { Adequacy } \\
\text { ratio }\end{array}$ & Availability & $\begin{array}{l}\text { Adequacy } \\
\text { ratio }\end{array}$ \\
\hline Calories & 2,266 & 0.91 & 2,576 & 1.03 & 2,004 & 0.80 \\
\hline Carbohydrates (gr) & 316.88 & 0.85 & 328.69 & 0.88 & 312.29 & 0.83 \\
\hline Animal proteins (gr) & 53.32 & 0.95 & 77.70 & 1.39 & 25.77 & 0.46 \\
\hline Vegatal proteins (gr) & 42.28 & 1.11 & 43.21 & 1.14 & 42.89 & 1.13 \\
\hline Animal fat (gr) & 51.27 & 1.83 & 71.56 & 2.56 & 29.36 & 1.05 \\
\hline Vegatal fat (gr) & 15.09 & 0.36 & 11.63 & 0.28 & 21.93 & 0.52 \\
\hline
\end{tabular}

Notes: Recommendations for nutrient intakes are taken from Tserennadmid (2011). For each household, two months of data from consumption diaries are used. Observations from February, April, July and October are excluded. Source: HIES/LSMS 2002/2003. 


\begin{tabular}{|c|c|c|c|}
\hline & \multicolumn{3}{|c|}{ Mean values } \\
\hline & $\begin{array}{l}\text { Small-scale } \\
\text { herding } \\
\text { households }\end{array}$ & $\begin{array}{l}\text { Large-scale } \\
\text { herding } \\
\text { households }\end{array}$ & $\begin{array}{l}\text { Non-herding } \\
\text { households }\end{array}$ \\
\hline & $\mathrm{N}=1,332$ & $\mathrm{~N}=449$ & $\mathrm{~N}=1,007$ \\
\hline Share of calories from own animal husbandry & 0.21 & 0.35 & 0 \\
\hline $\begin{array}{l}\text { Share of meat from own animal husbandry (out of total } \\
\text { consumed meat) }\end{array}$ & 0.57 & 0.86 & 0 \\
\hline Share of calories from meat & 0.21 & 0.26 & 0.14 \\
\hline $\begin{array}{l}\text { Share of consumed dairy products from own animal husbandry } \\
\text { (out of total consumed dairy products) }\end{array}$ & 0.44 & 0.72 & 0 \\
\hline Share of calories from dairy products & 0.09 & 0.12 & 0.05 \\
\hline Consumed crops from own farming & 0.15 & 0.14 & 0.04 \\
\hline Share of calories from own farming & 0.02 & 0.04 & 0.004 \\
\hline Prices paid for carrots (per kg) & 439 & 499 & 467 \\
\hline Prices paid for flour (per kg) & 317 & 314 & 320 \\
\hline Share of total monthly expenditures spent on food & 0.63 & 0.63 & 0.54 \\
\hline
\end{tabular}

Note: For each household, two months of data from consumption diaries are used. Observations from February, April, July and October are excluded. Source: HIES/LSMS 2002/2003. 
Table 4: Determinants of nutrient intake

\begin{tabular}{|c|c|c|c|c|c|c|c|c|}
\hline Dependent Variable & $\begin{array}{l}\text { Calories } \\
\text { (1) }\end{array}$ & $\begin{array}{l}\text { Carbo- } \\
\text { hydrates } \\
\text { (2) }\end{array}$ & $\begin{array}{c}\text { PROTEIN } \\
\text { (animal) } \\
\text { (3) }\end{array}$ & $\begin{array}{c}\text { PROTEIN } \\
\text { (vegetal) } \\
(4)\end{array}$ & $\begin{array}{c}\text { FAT } \\
\text { (animal) } \\
(5)\end{array}$ & $\begin{array}{c}\text { FAT } \\
\text { (vegetal) } \\
(6)\end{array}$ & $\begin{array}{l}\text { IRON } \\
\text { (7) }\end{array}$ & $\begin{array}{c}\text { Vitamin A } \\
\text { (8) }\end{array}$ \\
\hline \multirow{2}{*}{$\begin{array}{l}\text { Herder (1-99 } \\
\text { Livestock) }\end{array}$} & $0.100 * * *$ & $0.042 * *$ & $0.338 * * *$ & 0.023 & $0.321 * * *$ & -0.015 & $0.095 * * *$ & $0.304 * * *$ \\
\hline & $(0.018)$ & $(0.019)$ & $(0.035)$ & $(0.020)$ & $(0.038)$ & $(0.036)$ & $(0.024)$ & $(0.043)$ \\
\hline \multirow{2}{*}{$\begin{array}{l}\text { Full-time herder } \\
(100+\text { Livestock })\end{array}$} & $0.206^{* * *}$ & $0.095^{* * *}$ & $0.605 * * *$ & 0.047 & $0.587 * * *$ & -0.035 & $0.186^{* * *}$ & $0.531 * * *$ \\
\hline & $(0.030)$ & $(0.031)$ & $(0.053)$ & $(0.031)$ & $(0.058)$ & $(0.059)$ & $(0.035)$ & $(0.059)$ \\
\hline \multirow{2}{*}{ Income } & $0.156 * * *$ & $0.136^{* * *}$ & $0.189 * * *$ & $0.110^{* * *}$ & $0.223 * * *$ & $0.293 * * *$ & $0.120 * * *$ & $0.220 * * *$ \\
\hline & $(0.010)$ & $(0.011)$ & $(0.016)$ & $(0.011)$ & $(0.017)$ & $(0.017)$ & $(0.011)$ & $(0.020)$ \\
\hline \multirow{2}{*}{$\begin{array}{l}\text { Household lives at a } \\
\text { water source }\end{array}$} & -0.004 & -0.001 & 0.022 & -0.014 & -0.008 & -0.009 & -0.008 & $0.106 *$ \\
\hline & $(0.024)$ & $(0.026)$ & $(0.037)$ & $(0.030)$ & $(0.044)$ & $(0.041)$ & $(0.026)$ & $(0.054)$ \\
\hline \multirow{2}{*}{$\begin{array}{l}\text { Distance to the nearest } \\
\text { water source }\end{array}$} & 0.012 & -0.007 & $0.060 *$ & -0.009 & 0.029 & 0.019 & 0.024 & 0.046 \\
\hline & $(0.020)$ & $(0.022)$ & $(0.032)$ & $(0.025)$ & $(0.035)$ & V0.037) & $(0.024)$ & $(0.039)$ \\
\hline \multirow{2}{*}{ Vehicle ownership } & 0.023 & 0.023 & 0.014 & 0.018 & 0.025 & 0.034 & 0.002 & 0.027 \\
\hline & $(0.015)$ & $(0.017)$ & $(0.026)$ & $(0.018)$ & $(0.027)$ & $(0.029)$ & $(0.019)$ & $(0.030)$ \\
\hline \multirow{2}{*}{$\begin{array}{l}\text { Household lives at a } \\
\text { health center }\end{array}$} & -0.004 & -0.006 & -0.018 & -0.004 & -0.008 & 0.019 & -0.04 & 0.068 \\
\hline & $(0.027)$ & $(0.029)$ & $(0.048)$ & $(0.034)$ & $(0.049)$ & $(0.053)$ & $(0.032)$ & $(0.076)$ \\
\hline \multirow{2}{*}{$\begin{array}{l}\text { Distance to the nearest } \\
\text { health center }\end{array}$} & 0.015 & 0.001 & $0.048 *$ & -0.006 & $0.058 * *$ & -0.023 & -0.004 & $0.100^{* * *}$ \\
\hline & $(0.014)$ & $(0.015)$ & $(0.029)$ & $(0.018)$ & $(0.029)$ & $(0.028)$ & $(0.017)$ & $(0.033)$ \\
\hline \multirow[t]{2}{*}{ Household size } & $-0.062 * * *$ & $-0.053 * * *$ & $-0.088 * * *$ & $-0.052 * * *$ & $-0.080 * * *$ & $-0.052 * * *$ & $-0.067 * * *$ & $-0.090 * * *$ \\
\hline & $(0.004)$ & $(0.004)$ & $(0.007)$ & $(0.005)$ & $(0.008)$ & $(0.008)$ & $(0.006)$ & $(0.009)$ \\
\hline \multirow{2}{*}{$\begin{array}{l}\text { Share of children } \\
\text { under } 6 \text { in the } \\
\text { household }\end{array}$} & $0.219^{* * *}$ & $0.192 * * *$ & $0.373 * * *$ & $0.147 * *$ & $0.316^{* * *}$ & 0.076 & $0.288 * * *$ & $0.449 * * *$ \\
\hline & $(0.056)$ & V0.059) & $(0.085)$ & $(0.063)$ & $(0.090)$ & $(0.110)$ & $(0.064)$ & $(0.108)$ \\
\hline \multirow[t]{2}{*}{ Female Head } & -0.027 & -0.024 & -0.039 & -0.023 & -0.019 & -0.017 & -0.013 & -0.047 \\
\hline & $(0.020)$ & $(0.022)$ & $(0.032)$ & $(0.023)$ & $(0.038)$ & $(0.043)$ & $(0.026)$ & $(0.040)$ \\
\hline \multirow{2}{*}{$\begin{array}{l}\text { Education of most } \\
\text { senior woman }\end{array}$} & 0.002 & 0.000 & $0.012 * * *$ & -0.001 & 0.007 & $0.014 * * *$ & $-0.006^{*}$ & $0.014 * * *$ \\
\hline & $(0.002)$ & $(0.003)$ & $(0.004)$ & $(0.003)$ & $(0.004)$ & $(0.005)$ & $(0.003)$ & $(0.005)$ \\
\hline \multirow[t]{2}{*}{ Age of the head } & 0.000 & -0.001 & $0.003 * * *$ & -0.001 & $0.002 * *$ & $-0.002 *$ & 0.000 & $0.004 * *$ \\
\hline & $(0.001)$ & $(0.001)$ & $(0.001)$ & $(0.001)$ & $(0.001)$ & $(0.001)$ & $(0.001)$ & $(0.001)$ \\
\hline \multirow[t]{2}{*}{ District center } & -0.006 & $-0.058^{*}$ & $0.212 * * *$ & $-0.066^{* *}$ & $0.151^{* * *}$ & $-0.258 * * *$ & 0.007 & 0.039 \\
\hline & $(0.028)$ & $(0.030)$ & $(0.048)$ & $(0.032)$ & $(0.054)$ & $(0.059)$ & $(0.033)$ & $(0.059)$ \\
\hline \multirow[t]{2}{*}{ Rural } & $0.092 * *$ & -0.006 & $0.464 * * *$ & -0.036 & $0.392 * * *$ & $-0.395 * * *$ & $0.090 * *$ & $0.354 * * *$ \\
\hline & $(0.036)$ & $(0.035)$ & $(0.074)$ & $(0.038)$ & $(0.078)$ & $(0.075)$ & $(0.040)$ & $(0.081)$ \\
\hline \multirow[t]{2}{*}{ CPI } & $-1.245^{* *}$ & $-1.042 *$ & -0.406 & -0.679 & -1.634 & -1.553 & $-1.479 * *$ & $-3.546^{* * *}$ \\
\hline & $(0.588)$ & $(0.556)$ & $(1.171)$ & $(0.594)$ & $(1.090)$ & $(0.981)$ & $(0.687)$ & $(1.264)$ \\
\hline Month FE & yes & yes & yes & yes & yes & yes & yes & yes \\
\hline Province FE & yes & yes & yes & yes & yes & yes & yes & yes \\
\hline Number of households & 2788 & 2788 & 2783 & 2787 & 2784 & 2786 & 2788 & 2786 \\
\hline $\mathrm{R} 2$ & 0.323 & 0.204 & 0.461 & 0.156 & 0.37 & 0.366 & 0.339 & 0.283 \\
\hline
\end{tabular}

Notes: The dependent variables, income, the distance to the nearest water source and health center, and the price index are logarithmically transformed. For each distance measure, two variables are included (Battese (1997)): D and $\log ($ distance $+\mathrm{D})$, where D - here named "Household lives at a health center/ water source" - is a dummy variable that takes the value of one if the household reports a distance of zero or less than two $\mathrm{km}$ and zero otherwise. Displayed are coefficients estimated with OLS with $*$ significant at $10 \%$; $* *$ significant at $5 \%$; *** significant at $1 \%$ and standard errors in parentheses. For each household, two months of data from consumption diaries are used. Observations from February, April, July and October are excluded. Source: HIES/LSMS 2002/2003. 
Table 5: Nutrient wealth elasticities

\begin{tabular}{|c|c|c|c|c|c|c|c|c|}
\hline Dependent variables: & $\begin{array}{c}\text { Calories } \\
\text { (1) }\end{array}$ & $\begin{array}{c}\text { Carbo- } \\
\text { hydrates } \\
\text { (2) }\end{array}$ & $\begin{array}{c}\text { Animal } \\
\text { proteins } \\
\text { (3) }\end{array}$ & $\begin{array}{c}\text { Vegatal } \\
\text { proteins } \\
(4)\end{array}$ & $\begin{array}{c}\text { Animal } \\
\text { fat } \\
(5)\end{array}$ & $\begin{array}{l}\text { Vegatal } \\
\text { fat } \\
(6)\end{array}$ & $\begin{array}{l}\text { Iron } \\
\text { (7) }\end{array}$ & $\begin{array}{c}\text { Vitamin } \\
\text { A } \\
\text { (8) }\end{array}$ \\
\hline \multicolumn{9}{|c|}{ Panel A: Small-scale herding households } \\
\hline \multirow[t]{2}{*}{ Income } & $0.146^{* * *}$ & $0.132 * * *$ & $0.161^{* * *}$ & $0.105^{* * *}$ & $0.201 * * *$ & $0.285^{* * *}$ & $0.113^{* * *}$ & $0.188 * * *$ \\
\hline & $(0.012)$ & $(0.014)$ & $(0.023)$ & $(0.015)$ & $(0.025)$ & $(0.025)$ & $(0.015)$ & $(0.025)$ \\
\hline \multirow[t]{2}{*}{ Consumption expenditures } & $0.377 * * *$ & $0.291 * * *$ & $0.570 * * *$ & $0.230 * * *$ & $0.604 * * *$ & $0.506^{* * *}$ & $0.280^{* * *}$ & $0.668 * * *$ \\
\hline & $(0.016)$ & $(0.019)$ & $(0.028)$ & $(0.021)$ & $(0.033)$ & $(0.035)$ & $(0.022)$ & $(0.041)$ \\
\hline \multirow[t]{2}{*}{ Durables } & $0.032 * *$ & 0.017 & $0.078 * * *$ & 0.003 & $0.090 * * *$ & $0.049 *$ & 0.004 & $0.085^{* * *}$ \\
\hline & $(0.013)$ & $(0.014)$ & $(0.023)$ & $(0.014)$ & $(0.025)$ & $(0.028)$ & $(0.014)$ & $(0.029)$ \\
\hline \multirow[t]{2}{*}{ Instrumented income } & $0.140 * * *$ & $0.112 * * *$ & $0.211 * * *$ & $0.083 * * *$ & $0.250 * * *$ & $0.311 * * *$ & $0.143 * * *$ & $0.224 * * *$ \\
\hline & $(0.026)$ & $(0.027)$ & $(0.054)$ & $(0.029)$ & $(0.055)$ & $(0.056)$ & $(0.035)$ & $(0.057)$ \\
\hline \multirow[t]{2}{*}{ Instrumented cons. expenditures } & $0.192 * * *$ & $0.125^{* *}$ & $0.313 * * *$ & $0.095 *$ & $0.360 * * *$ & $0.588 * * *$ & $0.194 * * *$ & $0.299 * * *$ \\
\hline & $(0.046)$ & $(0.050)$ & $(0.080)$ & $(0.055)$ & $(0.088)$ & $(0.098)$ & $(0.063)$ & $(0.102)$ \\
\hline F-test instrumented income & 924.77 & 924.77 & 914.23 & 925.32 & 914.23 & 925.43 & 924.77 & 914.11 \\
\hline Adj. Partial R2 instrumented inc. & 0.250 & 0.250 & 0.250 & 0.250 & 0.248 & 0.250 & 0.250 & 0.250 \\
\hline F-test instrumented cons. expend. & 228.32 & 228.32 & 230.48 & 228.64 & 230.48 & 228.64 & 228.32 & 231.85 \\
\hline Adj. Partial R2 instr. cons expend. & 0.139 & 0.139 & 0.140 & 0.139 & 0.140 & 0.139 & 0.139 & 0.140 \\
\hline Number of households & 1,332 & 1,332 & 1,329 & 1,332 & 1,329 & 1,331 & 1,332 & 1,332 \\
\hline
\end{tabular}

Panel B: Large-scale herding households

\begin{tabular}{|c|c|c|c|c|c|c|c|c|}
\hline \multirow[t]{2}{*}{ Income } & $0.145^{* * *}$ & $0.130 * * *$ & $0.128 * * *$ & $0.113 * * *$ & $0.163 * * *$ & $0.296 * * *$ & $0.123 * * *$ & $0.119 * * *$ \\
\hline & $(0.018)$ & $(0.021)$ & $(0.029)$ & $(0.022)$ & $(0.026)$ & $(0.032)$ & $(0.021)$ & $(0.029)$ \\
\hline \multirow[t]{2}{*}{ Consumption expenditures } & $0.425 * * *$ & $0.335 * * *$ & $0.562 * * *$ & $0.315^{* * *}$ & $0.585 * * *$ & $0.612 * * *$ & $0.387 * * *$ & $0.599 * * *$ \\
\hline & $(0.032)$ & $(0.035)$ & $(0.050)$ & $(0.040)$ & $(0.053)$ & $(0.059)$ & $(0.034)$ & $(0.050)$ \\
\hline \multirow[t]{2}{*}{ Durables } & $0.033 *$ & 0.021 & 0.037 & 0.011 & $0.064 *$ & $0.070 *$ & 0.002 & $0.064 *$ \\
\hline & $(0.020)$ & $(0.020)$ & $(0.030)$ & $(0.023)$ & $(0.036)$ & $(0.038)$ & $(0.027)$ & $(0.033)$ \\
\hline \multirow[t]{2}{*}{ Instrumented income } & $0.161 * * *$ & $0.136 * * *$ & $0.156^{* * *}$ & $0.131 * * *$ & $0.235 * * *$ & $0.232 * * *$ & $0.200 * * *$ & $0.117 * *$ \\
\hline & $(0.038)$ & $(0.042)$ & $(0.059)$ & $(0.043)$ & $(0.052)$ & $(0.061)$ & $(0.044)$ & $(0.053)$ \\
\hline \multirow[t]{2}{*}{ Instrumented cons. expenditures } & $0.254 * * *$ & 0.15 & $0.249 * *$ & 0.158 & $0.501 * * *$ & $0.508 * * *$ & $0.283 * * *$ & $0.343 * * *$ \\
\hline & $(0.079)$ & $(0.096)$ & $(0.121)$ & $(0.104)$ & $(0.128)$ & $(0.130)$ & $(0.093)$ & $(0.118)$ \\
\hline F-test instrumented income & 304.86 & 304.86 & 304.75 & 304.86 & 304.75 & 304.86 & 304.86 & 304.86 \\
\hline Adj. Partial R2 instrumented inc. & 0.252 & 0.252 & 0.252 & 0.252 & 0.252 & 0.252 & 0.252 & 0.252 \\
\hline F-test instrumented cons. expend. & 63.67 & 63.67 & 63.57 & 63.67 & 63.57 & 63.67 & 63.67 & 63.67 \\
\hline Adj. Partial R2 instr. cons expend. & 0.095 & 0.095 & 0.095 & 0.095 & 0.095 & 0.095 & 0.095 & 0.095 \\
\hline Number of households & 449 & 449 & 448 & 449 & 448 & 449 & 449 & 449 \\
\hline
\end{tabular}




\begin{tabular}{|c|c|c|c|c|c|c|c|c|}
\hline Dependent variables: & $\begin{array}{c}\text { Calories } \\
\text { (1) }\end{array}$ & $\begin{array}{l}\text { Carbo- } \\
\text { hydrates } \\
\text { (2) }\end{array}$ & $\begin{array}{c}\text { Animal } \\
\text { proteins } \\
\text { (3) }\end{array}$ & $\begin{array}{c}\text { Vegatal } \\
\text { proteins } \\
\text { (4) }\end{array}$ & $\begin{array}{l}\text { Animal } \\
\text { fat } \\
(5)\end{array}$ & $\begin{array}{c}\text { Vegatal } \\
\text { fat } \\
(6)\end{array}$ & $\begin{array}{l}\text { Iron } \\
\text { (7) }\end{array}$ & $\begin{array}{c}\text { Vitamin } \\
\text { A } \\
(8)\end{array}$ \\
\hline \multicolumn{9}{|l|}{ Panel C: Non-herding households } \\
\hline Income & $\begin{array}{c}0.175^{* * *} \\
(0.015)\end{array}$ & $\begin{array}{c}0.143 * * * \\
(0.018)\end{array}$ & $\begin{array}{c}0.269 * * * \\
(0.023)\end{array}$ & $\begin{array}{c}0.116 * * * \\
(0.019)\end{array}$ & $\begin{array}{c}0.284 * * * \\
(0.027)\end{array}$ & $\begin{array}{c}0.304 * * * \\
(0.027)\end{array}$ & $\begin{array}{c}0.125^{* * *} \\
(0.019)\end{array}$ & $\begin{array}{c}0.357 * * * \\
(0.044)\end{array}$ \\
\hline Consumption expenditures & $\begin{array}{c}0.361 * * * \\
(0.016)\end{array}$ & $\begin{array}{c}0.317 * * * \\
(0.018)\end{array}$ & $\begin{array}{c}0.481 * * * \\
(0.023)\end{array}$ & $\begin{array}{c}0.275^{* * *} \\
(0.018)\end{array}$ & $\begin{array}{c}0.518 * * * \\
(0.029)\end{array}$ & $\begin{array}{c}0.538 * * * \\
(0.032)\end{array}$ & $\begin{array}{c}0.328 * * * \\
(0.021)\end{array}$ & $\begin{array}{c}0.591 * * * \\
(0.040)\end{array}$ \\
\hline Durables & $\begin{array}{l}0.018 \\
(0.012)\end{array}$ & $\begin{array}{l}0.003 \\
(0.012)\end{array}$ & $\begin{array}{c}0.081^{* * *} \\
(0.017)\end{array}$ & $\begin{array}{l}-0.001 \\
(0.013)\end{array}$ & $\begin{array}{c}0.070 * * * \\
(0.019)\end{array}$ & $\begin{array}{c}0.043^{* *} \\
(0.020)\end{array}$ & $\begin{array}{l}-0.015 \\
(0.016)\end{array}$ & $\begin{array}{c}0.098 * * * \\
(0.022)\end{array}$ \\
\hline Instrumented income & $\begin{array}{c}0.224 * * * \\
(0.035)\end{array}$ & $\begin{array}{c}0.180^{* * *} \\
(0.038)\end{array}$ & $\begin{array}{c}0.369 * * * \\
(0.052)\end{array}$ & $\begin{array}{c}0.141^{* * *} \\
(0.041)\end{array}$ & $\begin{array}{c}0.368 * * * \\
(0.061)\end{array}$ & $\begin{array}{c}0.468^{* * *} \\
(0.066)\end{array}$ & $\begin{array}{c}0.163 * * * \\
(0.045)\end{array}$ & $\begin{array}{c}0.476^{* * *} \\
(0.084)\end{array}$ \\
\hline Instrumented cons. expenditures & $\begin{array}{c}0.318^{* * *} \\
(0.046)\end{array}$ & $\begin{array}{c}0.248^{* * * *} \\
(0.054)\end{array}$ & $\begin{array}{c}0.546^{* * *} \\
(0.078)\end{array}$ & $\begin{array}{c}0.186^{* * *} \\
(0.057)\end{array}$ & $\begin{array}{c}0.483 * * * \\
(0.086)\end{array}$ & $\begin{array}{c}0.723 * * * \\
(0.095)\end{array}$ & $\begin{array}{c}0.308^{* * *} \\
(0.068)\end{array}$ & $\begin{array}{c}0.644^{* * *} \\
(0.097)\end{array}$ \\
\hline F-test instrumented income & 352.78 & 352.78 & 351.12 & 352.75 & 352.30 & 352.75 & 352.78 & 352.57 \\
\hline Adj. Partial R2 instrumented inc. & 0.169 & 0.169 & 0.169 & 0.169 & 0.169 & 0.169 & 0.169 & 0.170 \\
\hline F-test instrumented cons. expend. & 204.38 & 204.38 & 203.87 & 204.21 & 203.9 & 204.21 & 204.38 & 215.68 \\
\hline Adj. Partial R2 instr. cons expend. & 0.108 & 0.108 & 0.108 & 0.109 & 0.108 & 0.109 & 0.108 & 0.11 \\
\hline Number of households & 1,007 & 1,007 & 1,006 & 1,006 & 1,006 & 1,006 & 1,007 & 1,006 \\
\hline
\end{tabular}

Notes: All dependent variables and all wealth measures are logarithmically transformed. All regressions include the complete set of controls as in table 4. Income is instrumented by the median income in the enumeration area. Consumption expenditures are instrumented by the median non-food expenditures in the enumeration area. Displayed are coefficients estimated with OLS and IV with * significant at $10 \%$; ** significant at 5\%; *** significant at $1 \%$ and standard errors in parentheses. For each household, two months of data from consumption diaries are used. Observations from February, April, July and October are excluded. Source: HIES/LSMS 2002/2003. 
Table 6: The effect of food self-provisioning

\begin{tabular}{|c|c|c|c|c|c|c|c|c|}
\hline Dependent variables: & $\begin{array}{l}\text { Calories } \\
\text { (1) }\end{array}$ & $\begin{array}{l}\text { Carbo- } \\
\text { hydrates } \\
\text { (2) }\end{array}$ & $\begin{array}{l}\text { Animal } \\
\text { proteins } \\
\text { (3) }\end{array}$ & $\begin{array}{l}\text { Vegatal } \\
\text { proteins } \\
\text { (4) }\end{array}$ & $\begin{array}{l}\text { Animal fat } \\
\text { (5) }\end{array}$ & $\begin{array}{c}\text { Vegatal fat } \\
\text { (6) }\end{array}$ & $\begin{array}{l}\text { Iron } \\
\text { (7) }\end{array}$ & $\begin{array}{c}\text { Vitamin A } \\
\text { (8) }\end{array}$ \\
\hline \multicolumn{9}{|c|}{ Panel A: Small-scale herding households } \\
\hline Income & $\begin{array}{c}0.157 * * * \\
(0.013)\end{array}$ & $\begin{array}{c}0.142 * * * \\
(0.014)\end{array}$ & $\begin{array}{c}0.167 * * * \\
(0.021)\end{array}$ & $\begin{array}{c}0.116^{* * * *} \\
(0.015)\end{array}$ & $\begin{array}{c}0.208 * * * \\
(0.024)\end{array}$ & $\begin{array}{c}0.295 * * * \\
(0.029)\end{array}$ & $\begin{array}{c}0.123 * * * \\
(0.017)\end{array}$ & $\begin{array}{c}0.185^{* * *} \\
(0.027)\end{array}$ \\
\hline $\begin{array}{l}\text { Share of calories from } \\
\text { own animal husbandry }\end{array}$ & $\begin{array}{c}0.363 * * * \\
(0.080)\end{array}$ & $\begin{array}{c}-0.551^{* * *} \\
(0.088)\end{array}$ & $\begin{array}{c}2.518 * * * \\
(0.125)\end{array}$ & $\begin{array}{c}-0.879 * * * \\
(0.087)\end{array}$ & $\begin{array}{c}2.705 * * * \\
(0.119)\end{array}$ & $\begin{array}{c}-1.435 * * * \\
(0.158)\end{array}$ & $\begin{array}{l}-0.037 \\
\text { V0.090) }\end{array}$ & $\begin{array}{c}2.485^{* * *} \\
(0.151)\end{array}$ \\
\hline $\begin{array}{l}\text { Consumed crops from } \\
\text { own farming }\end{array}$ & $\begin{array}{c}0.056^{* *} \\
(0.023)\end{array}$ & $\begin{array}{c}0.075 * * * \\
(0.025)\end{array}$ & $\begin{array}{l}0.004 \\
(0.032)\end{array}$ & $\begin{array}{c}0.070 * * * \\
(0.026)\end{array}$ & $\begin{array}{l}-0.017 \\
(0.037)\end{array}$ & $\begin{array}{c}0.127 * * \\
(0.050)\end{array}$ & $\begin{array}{l}0.040 \\
(0.025)\end{array}$ & $\begin{array}{l}0.02 \\
(0.036)\end{array}$ \\
\hline $\begin{array}{l}\text { Income * Share of } \\
\text { calories }\end{array}$ & $\begin{array}{l}-0.061 \\
(0.063)\end{array}$ & $\begin{array}{l}-0.010 \\
(0.068)\end{array}$ & $\begin{array}{c}-0.212 * * \\
(0.102)\end{array}$ & $\begin{array}{l}0.034 \\
(0.069)\end{array}$ & $\begin{array}{c}-0.299 * * * \\
(0.105)\end{array}$ & $\begin{array}{l}0.114 \\
(0.111)\end{array}$ & $\begin{array}{l}0.087 \\
(0.077)\end{array}$ & $\begin{array}{c}-0.444 * * * \\
(0.126)\end{array}$ \\
\hline $\begin{array}{l}\text { Income } * \text { Consumed } \\
\text { crops }\end{array}$ & $\begin{array}{l}-0.040 \\
(0.026)\end{array}$ & $\begin{array}{l}-0.029 \\
(0.027)\end{array}$ & $\begin{array}{l}-0.032 \\
(0.034)\end{array}$ & $\begin{array}{l}-0.032 \\
(0.026)\end{array}$ & $\begin{array}{l}-0.034 \\
(0.040)\end{array}$ & $\begin{array}{l}-0.025 \\
(0.053)\end{array}$ & $\begin{array}{l}-0.041 \\
(0.026)\end{array}$ & $\begin{array}{l}0.015 \\
(0.040)\end{array}$ \\
\hline Number of households & 1,332 & 1,332 & 1,329 & 1,332 & 1,329 & 1,331 & 1,332 & 1,332 \\
\hline R-squared & 0.361 & 0.267 & 0.555 & 0.245 & 0.537 & 0.412 & 0.337 & 0.414 \\
\hline
\end{tabular}

Panel B: Large-scale herding households

\begin{tabular}{|c|c|c|c|c|c|c|c|c|}
\hline \multirow[t]{2}{*}{ Income } & $0.147 * * *$ & $0.125 * * *$ & $0.136^{* * *}$ & $0.104 * * *$ & $0.181 * * *$ & $0.311 * * *$ & $0.126 * * *$ & $0.123 * * *$ \\
\hline & $(0.019)$ & $(0.021)$ & $(0.027)$ & $(0.022)$ & $(0.020)$ & $(0.031)$ & $(0.022)$ & $(0.031)$ \\
\hline \multirow{2}{*}{$\begin{array}{l}\text { Share of calories from } \\
\text { own animal husbandry }\end{array}$} & $0.385 * * *$ & $-0.803 * * *$ & $2.502 * * *$ & $-1.089 * * *$ & $2.935 * * *$ & $-1.713 * * *$ & 0.120 & $2.386^{* * *}$ \\
\hline & $(0.115)$ & $(0.118)$ & $(0.176)$ & $(0.150)$ & $(0.179)$ & $(0.233)$ & $(0.155)$ & $(0.196)$ \\
\hline \multirow{2}{*}{$\begin{array}{l}\text { Consumed crops from } \\
\text { own farming }\end{array}$} & 0.030 & 0.037 & 0.032 & 0.048 & 0.024 & 0.123 & 0.048 & 0.024 \\
\hline & $(0.037)$ & $(0.040)$ & $(0.044)$ & $(0.040)$ & $(0.047)$ & $(0.075)$ & $(0.046)$ & $(0.044)$ \\
\hline \multirow{2}{*}{$\begin{array}{l}\text { Income * Share of } \\
\text { calories }\end{array}$} & -0.006 & 0.068 & -0.037 & 0.088 & -0.124 & 0.057 & 0.083 & -0.016 \\
\hline & $(0.092)$ & $(0.112)$ & $(0.131)$ & $(0.111)$ & $(0.134)$ & $(0.151)$ & $(0.091)$ & $(0.164)$ \\
\hline \multirow{2}{*}{$\begin{array}{l}\text { Income } * \text { Consumed } \\
\text { crops }\end{array}$} & 0.001 & 0.007 & 0.006 & 0.014 & -0.017 & -0.076 & -0.011 & 0.021 \\
\hline & $(0.030)$ & $(0.033)$ & $(0.042)$ & $(0.033)$ & $(0.034)$ & $(0.050)$ & $(0.038)$ & $(0.043)$ \\
\hline Number of households & 449 & 449 & 448 & 449 & 448 & 449 & 449 & 449 \\
\hline R-squared & 0.459 & 0.385 & 0.59 & 0.354 & 0.646 & 0.466 & 0.452 & 0.541 \\
\hline \multicolumn{9}{|c|}{ Panel C: Non-herding households } \\
\hline \multirow[t]{2}{*}{ Income } & $0.181 * * *$ & $0.149 * * *$ & $0.273 * * *$ & $0.124 * * *$ & $0.286 * * *$ & $0.313 * * *$ & $0.132 * * *$ & $0.368 * * *$ \\
\hline & $(0.016)$ & $(0.018)$ & $(0.024)$ & $(0.019)$ & $(0.028)$ & $(0.028)$ & $(0.020)$ & $(0.046)$ \\
\hline \multirow{2}{*}{$\begin{array}{l}\text { Consumed crops from } \\
\text { own farming }\end{array}$} & 0.061 & $0.090 * *$ & 0.051 & $0.084 *$ & 0.051 & 0.049 & $0.138 * * *$ & -0.014 \\
\hline & $(0.044)$ & $(0.046)$ & $(0.060)$ & $(0.048)$ & $(0.067)$ & $(0.076)$ & $(0.043)$ & $(0.151)$ \\
\hline \multirow{2}{*}{$\begin{array}{l}\text { Income } * \text { Consumed } \\
\text { crops }\end{array}$} & $-0.119 * *$ & $-0.121 * * *$ & -0.07 & $-0.137 * * *$ & -0.053 & $-0.164 * *$ & $-0.137 * * *$ & $-0.209 * *$ \\
\hline & $(0.047)$ & $(0.046)$ & $(0.068)$ & $(0.049)$ & $(0.081)$ & $(0.073)$ & $(0.047)$ & $(0.096)$ \\
\hline Number of households & 1,007 & 1,007 & 1,006 & 1,007 & 1,007 & 1,007 & 1,007 & 1,007 \\
\hline R-squared & 0.243 & 0.185 & 0.279 & 0.156 & 0.200 & 0.210 & 0.198 & 0.194 \\
\hline
\end{tabular}

Notes: All dependent variables and income are logarithmically transformed. Income and share of calories from own animal husbandry have been centered to allow for an easier interpretation of the interaction terms. All regressions include the complete set of controls as in table 4. Displayed are coefficients estimated with OLS with * significant at $10 \%$; * significant at $5 \%$; *** significant at $1 \%$ and standard errors in parentheses. For each household, two months of data from consumption diaries are used. Observations from February, April, July and October are excluded. Source: HIES/LSMS 2002/2003. 
Table 7: The impact of dzud on the intake of nutrients

\begin{tabular}{|c|c|c|c|c|c|c|c|c|}
\hline Dependent Variable & $\begin{array}{c}\text { Calories } \\
\text { (1) }\end{array}$ & $\begin{array}{c}\text { Carbo- } \\
\text { hydrates } \\
\text { (2) }\end{array}$ & $\begin{array}{c}\text { Animal } \\
\text { proteins } \\
(3)\end{array}$ & $\begin{array}{c}\text { Vegatal } \\
\text { proteins } \\
(4)\end{array}$ & $\begin{array}{c}\text { Animal } \\
\text { fat } \\
(5)\end{array}$ & $\begin{array}{c}\text { Vegatal } \\
\text { fat } \\
(6)\end{array}$ & $\begin{array}{l}\text { Iron } \\
\text { (7) }\end{array}$ & $\begin{array}{c}\text { Vitamin A } \\
\text { (8) }\end{array}$ \\
\hline \multicolumn{9}{|c|}{ Panel A: Small-scale herding households } \\
\hline \multirow[t]{2}{*}{ Sheep losses in 2002} & -0.042 & -0.027 & -0.047 & -0.020 & $-0.128 * *$ & -0.029 & -0.014 & -0.014 \\
\hline & 0.032 & 0.031 & 0.044 & 0.031 & 0.058 & 0.064 & 0.032 & 0.033 \\
\hline \multirow[t]{2}{*}{ Income } & $0.152 * * *$ & $0.139 * * *$ & $0.159 * * *$ & $0.112 * * *$ & $0.202 * * *$ & $0.285 * * *$ & $0.114 * * *$ & $0.183 * * *$ \\
\hline & 0.013 & 0.013 & 0.021 & 0.014 & 0.025 & 0.029 & 0.016 & 0.027 \\
\hline \multirow{2}{*}{$\begin{array}{l}\text { Share of calories from own } \\
\text { animal husbandry }\end{array}$} & $0.315^{* * *}$ & $-0.603 * * *$ & $2.435 * * *$ & $-0.943 * * *$ & $2.649 * * *$ & $-1.475^{* * *}$ & -0.088 & $2.444 * * *$ \\
\hline & 0.08 & 0.087 & 0.127 & 0.086 & 0.118 & 0.161 & 0.09 & 0.156 \\
\hline \multirow{2}{*}{$\begin{array}{l}\text { Consumed crops from own } \\
\text { farming }\end{array}$} & $0.046^{* *}$ & $0.061 * * *$ & -0.003 & $0.057 * *$ & -0.012 & $0.124 * *$ & 0.033 & 0.006 \\
\hline & 0.022 & 0.023 & 0.032 & 0.025 & 0.034 & 0.052 & 0.025 & 0.037 \\
\hline \multirow[t]{2}{*}{ Income*Share of calories } & -0.071 & -0.021 & $-0.241 * *$ & 0.013 & $-0.314 * * *$ & 0.126 & 0.081 & $-0.444 * * *$ \\
\hline & 0.063 & 0.066 & 0.104 & 0.068 & 0.107 & 0.111 & 0.077 & 0.128 \\
\hline \multirow[t]{2}{*}{ Income*Consumed crops } & -0.032 & -0.024 & -0.018 & -0.026 & -0.023 & -0.008 & -0.041 & 0.016 \\
\hline & 0.025 & 0.025 & 0.035 & 0.025 & 0.039 & 0.052 & 0.025 & 0.041 \\
\hline \multirow[t]{2}{*}{ Sheep losses*Share of calories } & $-0.211 * *$ & $-0.258 * * *$ & $-0.268^{*}$ & -0.143 & -0.079 & 0.024 & -0.070 & $-0.343 * *$ \\
\hline & 0.092 & 0.089 & 0.145 & 0.088 & 0.138 & 0.153 & 0.128 & 0.147 \\
\hline \multirow[t]{2}{*}{ Sheep losses $*$ Consumed crops } & 0.008 & 0.008 & 0.010 & -0.010 & -0.031 & -0.031 & $-0.044 *$ & -0.013 \\
\hline & 0.029 & 0.026 & 0.043 & 0.028 & 0.062 & 0.061 & 0.026 & 0.039 \\
\hline Number of households & 1,267 & 1,267 & 1,265 & 1,267 & 1,265 & 1,266 & 1,267 & 1,266 \\
\hline R-squared & 0.385 & 0.299 & 0.563 & 0.278 & 0.544 & 0.422 & 0.351 & 0.421 \\
\hline \multicolumn{9}{|c|}{ Panel B: Large-scale herding households } \\
\hline \multirow[t]{2}{*}{ Sheep losses in 2002} & -0.021 & -0.010 & -0.005 & 0.000 & $-0.053 *$ & 0.040 & -0.001 & 0.013 \\
\hline & $(0.028)$ & $(0.028)$ & $(0.055)$ & $(0.036)$ & $(0.030)$ & $(0.046)$ & $(0.038)$ & $(0.053)$ \\
\hline \multirow[t]{2}{*}{ Income } & $0.143 * * *$ & $0.122 * * *$ & $0.129 * * *$ & $0.102 * * *$ & $0.183 * * *$ & $0.311 * * *$ & $0.123 * * *$ & $0.113 * * *$ \\
\hline & $(0.019)$ & $(0.021)$ & $(0.028)$ & $(0.022)$ & $(0.020)$ & $(0.030)$ & $(0.023)$ & $(0.029)$ \\
\hline \multirow{2}{*}{$\begin{array}{l}\text { Share of calories from own } \\
\text { animal husbandry }\end{array}$} & $0.358 * * *$ & $-0.821 * * *$ & $2.469 * * *$ & $-1.104 * * *$ & $2.901 * * *$ & $-1.712 * * *$ & 0.103 & $2.361^{* * *}$ \\
\hline & $(0.115)$ & $(0.119)$ & $(0.184)$ & $(0.151)$ & $(0.166)$ & $(0.241)$ & $(0.159)$ & $(0.199)$ \\
\hline \multirow{2}{*}{$\begin{array}{l}\text { Consumed crops from own } \\
\text { farming }\end{array}$} & 0.028 & 0.034 & 0.028 & 0.045 & 0.026 & $0.121^{*}$ & 0.052 & 0.016 \\
\hline & $(0.037)$ & $(0.041)$ & $(0.042)$ & $(0.041)$ & $(0.047)$ & $(0.073)$ & $(0.045)$ & $(0.041)$ \\
\hline \multirow[t]{2}{*}{ Income*Share of calories } & 0.007 & 0.078 & -0.001 & 0.095 & -0.151 & 0.074 & 0.096 & 0.041 \\
\hline & $(0.092)$ & $(0.111)$ & $(0.123)$ & $(0.110)$ & $(0.128)$ & $(0.153)$ & $(0.092)$ & $(0.157)$ \\
\hline \multirow[t]{2}{*}{ Income*Consumed crops } & 0.002 & 0.007 & 0.010 & 0.014 & -0.019 & -0.074 & -0.008 & 0.026 \\
\hline & $(0.030)$ & $(0.033)$ & $(0.042)$ & $(0.032)$ & $(0.035)$ & $(0.050)$ & $(0.039)$ & $(0.041)$ \\
\hline \multirow[t]{2}{*}{ Sheep losses*Share of calories } & -0.067 & -0.019 & -0.090 & 0.041 & $0.263 *$ & 0.186 & -0.126 & -0.291 \\
\hline & $(0.101)$ & $(0.104)$ & $(0.170)$ & $(0.129)$ & $(0.140)$ & $(0.189)$ & $(0.141)$ & $(0.189)$ \\
\hline \multirow[t]{2}{*}{ Sheep losses*Consumed crops } & 0.002 & 0.003 & -0.010 & -0.001 & -0.015 & -0.024 & -0.026 & 0.015 \\
\hline & $(0.026)$ & $(0.026)$ & $(0.053)$ & $(0.026)$ & $(0.034)$ & $(0.077)$ & $(0.048)$ & $(0.057)$ \\
\hline Number of households & 449 & 449 & 448 & 449 & 448 & 449 & 449 & 449 \\
\hline R-squared & 0.461 & 0.388 & 0.592 & 0.358 & 0.653 & 0.47 & 0.453 & 0.546 \\
\hline
\end{tabular}

Notes: All dependent variables and income are logarithmically transformed. All regressions include the complete set of controls as in table 4. Displayed are coefficients estimated with OLS with * significant at $10 \%$; ** significant at $5 \%$; *** significant at $1 \%$ and standard errors in parentheses. For each household, two months of data from consumption diaries are used. Observations from February, April, July and October are excluded. Source: HIES/LSMS 2002/2003. 